Universidade de Brasília

Centro de Excelência em Turismo

\title{
SPA ZEN ARTE VIVENDA
}

Proposta para o Ecoturismo

\section{Rosa Iida}

Matrícula 200242.594

Professor Doutor Manoel Cláudio da Silva Júnior

Brasília, DF, 25 de março de 2003 
Universidade de Brasília

Centro de Excelência em Turismo

\section{SPA ZEN ARTE VIVENDA}

Proposta para o Ecoturismo

\section{Rosa Iida}

Matrícula 200242.594

Menção:

Professor Doutor Manoel Cláudio da Silva Júnior

Monografia apresentada ao Centro de Excelência em Turismo da Universidade de Brasília como requisito parcial para obtenção do certificado de Especialista em Ecoturismo.

Brasília, DF, 25 de março de 2003 
Iida, Rosa

Spa Zen Arte Vivenda/ Rosa Iida

Monografia (Especialização)- Universidade de Brasília. Centro de Excelência em Turismo. Brasília, 2003.

53 páginas

Área de concentração: sustentabilidade ecoturística

Orientador: Professor Doutor Manoel Cláudio da Silva Junior.

1. Ecoturismo 2. Sustentabilidade 3. Comunidade 


\section{Agradecimentos}

Ao Professor Doutor Manoel Cláudio, por sua generosa paciência e dedicação; Aos irmãos Paulo Yida e Violeta Y. Yin, pelo constante e valioso apoio; Aos amigos Jovita Madeira, Wallace, Sylvio, Márcio e Jefté, pela colaboração técnica e finalmente;

Às minhas filhas Luanda, Ludmilla e Soraya I. de Carvalho, grandes incentivadoras na minha especialização, impondo - me desafios e conseqüente crescimento no trabalho monográfico que hoje concluo e entrego para a devida avaliação. 


\section{RESUMO}

O ano de 2.002 foi o Ano Internacional do Ecoturismo e por essa razão atraiu e vem atraindo atenção de todos: Governo, empresários, ecoturistas e a comunidade na busca de informações para implementação de projetos ecoturísticos. A permacultura é uma forma de utilização abrangente do espaço, regida por princípios ecológicos, visando a conservação da energia do ambiente e as ecovilas são edificações das comunidades que optaram por viver integrados à natureza, garantindo suas necessidades básicas e saudáveis de água, alimento, interação social e trabalho.

São propostas que se adeqüam aos projetos ecoturísticos que visam o envolvimento comunitário, a geração de empregos locais, a conservação da natureza, o compromisso com a educação ambiental, tudo isso em bases sustentáveis. O SPA ZEN ARTE VIVENDA, localizado na APA Gama Cabeça de Veado, já em funcionamento, tem proposta semelhante. Desta forma, o objetivo principal dessa monografia foi a avaliação do SPA ZEN à luz das técnicas de permacultura e funcionamento de ecovilas, apresentando sugestões ou adaptações para a sustentabilidade do empreendimento. 


\begin{abstract}
2002 was the International Ecotourism Year and in this way has attracted the Government, business mon, ecotourists and community attention, looking for information on ecotourism projects implementation. Permaculture is an strategy based on ecological principles aiming energy and environmental conservation for a broad utilization of space, and ecovillages are communities which choose to live on sustainable basis on their water, food, work and social relationships resources are adequate techniques for ecotourism projects, once they aim to estimulate community participation, creation of local jobs, nature conservation and environmental education, on sustainable basis. "The SPA ZEN -ARTE VIVENDA" in the "Gama - Cabeça de Veado" environmental protected area is already functioning and has similar aims. In this way, the main objective of the present study was to assess 'SPA-ZEN' area on the basis of permaculture techniques and ecovillages functioning in order to suggest sustainable strategies for the SPA ZEN.
\end{abstract}




\section{SUMÁRIO}

Resumo.

Pág.

Abstract

Índice de Figuras

$\mathrm{V}$

1 - Introdução.

Viii

1.1 O Problema

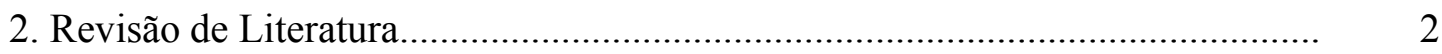

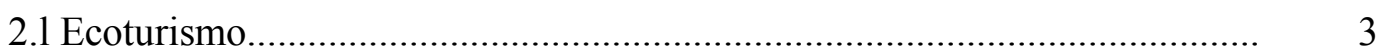

2.2 As principais atividades ecoturísticas no Brasil............................................... 6

2.3.Instalações Ecoturísticas...................................................................... 7

2.3.1 - Projeto de edificações................................................................ 7

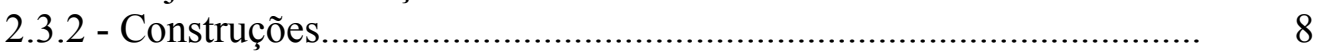

2.3.3 - Fonte de Poluição................................................................................ 8

2.3.4 - Organização do espaço........................................................................ 8

2.3.5 - Trato com ambiente natural.......................................................... 8

2.3.6 - Trilhas e sinalizações..................................................................... 9

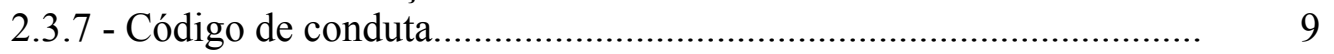

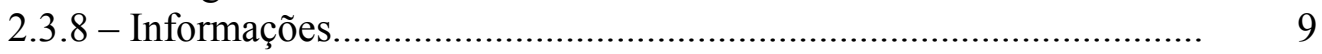

2.3.9 - Consumo de energia....................................................................... 9

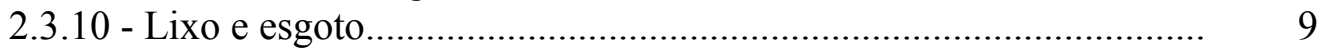

2.3.11 - Produção de alimentos.................................................................... 10

2.4 - Baixo Impacto....................................................................... 10

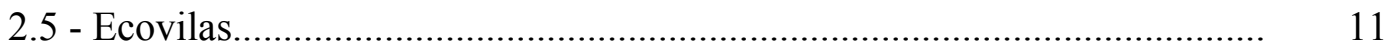

2.5.1 - Sistemas de captação, armazenagem e reciclagem da água.............. 11

2.5.2 - Sistemas de geração de energia renovável........................................ 12

2.5.3 - Redução das necessidades de transporte.......................................... 13

2.5.4 - Acesso à facilidade de comunicação............................................... 13

2.5.5 - Estruturas físicas.......................................................................... 14

2.5.6 - Produção e consumo de alimentos e necessidades básicas............. 14

2.5.7 - Arquitetura e construção ecológica................................................... 15

2.5.8 - Considerações ao ciclo de vida dos materiais................................. 16

2.5.9 - Restauração dos ecossistemas....................................................... 16

2.5.10 - Estruturas sociais e econômicas..................................................... 17

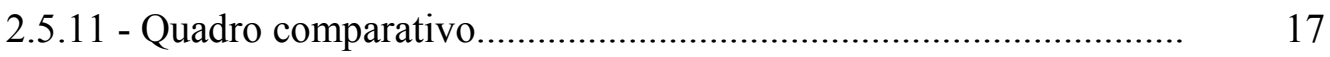

2.5.12 - Sistemas econômicos locais....................................................... 18

2.5.13 - Sistema de saúde preventiva.......................................................... 18

2.5.14 - Educação para as realidades........................................................... 18

2.5.15 - Estruturas culturais.............................................................. 19 
2.7 - Planejamento por zonas....................................................................... 20

2.8 - Técnicas para construções de habitações saudáveis................................... 23

2.9 - Sanitário Compostável........................................................................ 25

3 - Material e Métodos................................................................................... 28

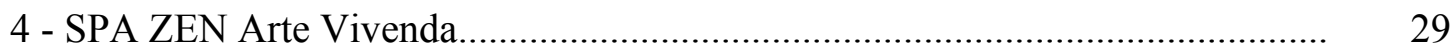

4.1 - Histórico do SPA ZEN por José Noguchi, Artista Plástico, Ambientalista, Proprietário, brasileiro nissei, 52 anos................................... 30

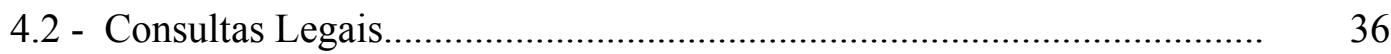

4.3 - Instalações atuais................................................................................... 37

4.4 - Resultados e Discussões........................................................................... 44

5 - Considerações Finais........................................................................................ $\quad 50$

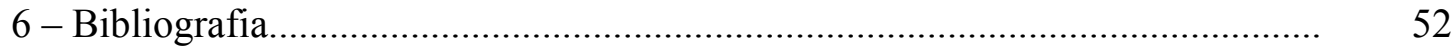

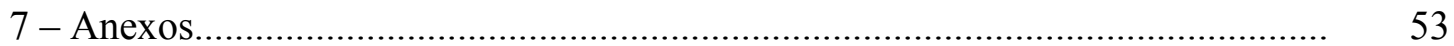




\section{ÍNDICE DE FIGURAS}

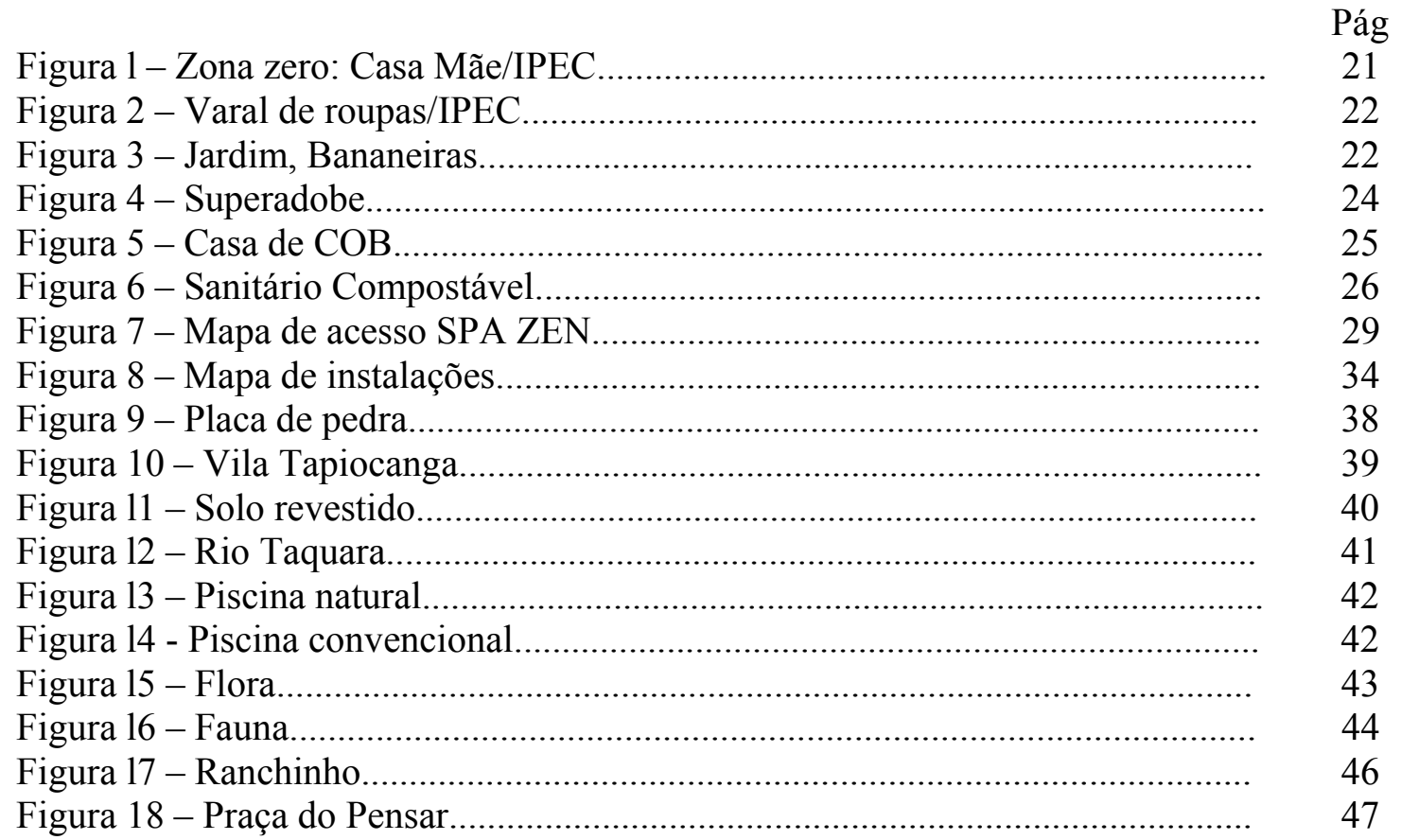




\section{INTRODUÇÃO}

O SPA ZEN ARTE VIVENDA é um espaço natural, multitemático, cercado por grandes reservas ecológicas, Fazenda Água Limpa, da Universidade de Brasília-UnB, Instituto Brasileiro de Geografia e Estatística-IBGE, Aeronáutica e Jardim Botânico de Brasília.

Tem a proposta de empreendimento ecoturístico e foi objeto de visita da turma de alunos pós-graduandos do Centro de Excelência de Turismo da Universidade de Brasília CET/UnB, no módulo oferecido pela Professora Jeanine Felfili. Após esse primeiro contato, a autora fez várias outras visitas ao SPA ZEN, mantendo contacto com o proprietário Noguchi e funcionários para as avaliações iniciais. Posteriormente, visitou o Instituto de Permacultura e Ecovilas do Cerrado - IPEC, em Pirenópolis, acompanhada do Prof.Manuel Cláudio e de uma colega de curso Olga, com a finalidade de se observar as técnicas de construção e manejo usadas na comunidade, visando a auto-sustentabilidade. Há nos dois empreendimentos forte destaque para a valorização da natureza e a aplicação da criatividade em todos os sentidos para a conservação da mesma.

Neste sentido, o presente trabalho tem por objetivo avaliar o espaço SPA ZEN Arte Vivenda, à luz das técnicas de permacultura e funcionamento de Ecovilas, visando apresentar sugestões para a sustentabilidade do empreendimento.O trabalho monográfico tem inicio com a revisão de literatura sobre os temas de Ecoturismo, Ecovilas, Permacultura atentando-se para os principais pontos da sustentabilidade. Em seguida, no material e métodos, apresenta-se a caracterização do SPA ZEN, inserida na Área de Proteção Ambiental Gama Cabeça de Veado-APA. São comentadas no capítulo resultados e discussão e sugeridas também as adaptações e sugestões, que sem esgotar o assunto, devem ser considerados para a sustentabilidade do empreendimento. 


\subsection{O PROBLEMA}

A implantação de um projeto de ecoturismo, como o do SPA ZEN, exigiu e exige um intricado conjunto de normas e detalhamentos e entre as maiores dificuldades pode-se citar:

1) Não há consenso sobre a definição do termo ecoturismo que surgiu na década de 80, o que dificulta também a classificação do empreendimento como ecoturístico ou não.

2) Falta educação ambiental básica e informações por parte da população sobre ecologia do cerrado, seu uso e restrições na Gama Cabeça-de-Veado-APA, onde está situado o SPA ZEN. Ao mesmo tempo, essa comunidade desconhece os seus direitos de participação na gestão da Área de Proteção Ambiental Gama Cabeça de Veado - APA para um meio ambiente ecologicamente equilibrado;

3) Falta entrosamento entre os especialistas no assunto e a comunidade local que inclui membros dos centros urbanos e de áreas rurais.

Um dos grandes potenciais do SPA ZEN na Área de Proteção Ambiental Gama Cabeça de Veado - APA é a consolidação da consciência ambiental da comunidade local e dos ecoturistas que terão a possibilidade de vivenciar o funcionamento de estratégias sustentáveis que visem o menor impacto, a educação e a diversão dos participantes.

É possível assim, que essas estratégias sejam incorporadas no dia-a -dia dos participantes em suas casas e locais de trabalho, aumentando assim a qualidade de vida geral, bem como a recuperação e conservação da Área de Proteção Ambiental Gama Cabeça de Veado - APA. 


\section{REVISÃO DE LITERATURA}

\section{I - ECOTURISMO}

O crescimento da população, confinado a espaços irrisórios, fez aumentar o desconforto urbano devido à infra-estrutura precária da saúde pública, transporte e conforto. Em resposta a esse congestionamento, as pessoas da nobreza e burguesias começaram a procurar o campo, em busca de ambiente saudável, espaço e tranqüilidade. $\mathrm{E}$ nessa época, surgiram estações termais, estâncias da montanha e pousadas, conforme pontua Western - no seguinte relato: "O Ecoturismo explodiu no mundo das viagens e da conservação com um tsunami (maremoto): porém suas origens são definitivamente mais evolutivas que revolucionárias. As raízes do ecoturismo encontram-se na natureza e no turismo ao ar livre. Os visitantes que, há um século, chegaram em massa aos parques nacionais de Yellostone e Yosemite foram os primeiros ecoturistas. Os viajantes pioneiros que se embrenharam há 50 anos e os aventureiros caminhantes do Himalaia que acamparam no Annapurnas 25 anos mais tarde eram tão ecoturistas quanto milhares que hoje fotografam os pingüins da Antártida, ou que dormem nas habitações comunitárias como a ecovilas que estão surgindo no mundo atual."

No Brasil, as origens do ecoturismo podem ser situadas no ano de 1841, na façanha do botânico escocês George Gardner por conquistar os 2.263m da Pedra do Sino, localizada na cidade de Teresópolis-R. J.

Para WCU - World Conservation Union, (1997) “..o ecoturismo é uma modalidade turística ambientalmente responsável, que tem por objetivo desfrutar, apreciar ou estudar os atrativos naturais e culturais de determinadas localidades".

Para Western (1997) “ecoturismo é a viagem responsável a áreas naturais, visando preservar o meio ambiente e a promover o bem estar da população local, e é mais do que

uma pequena elite de amantes de natureza. É na verdade, um amalgama de interesses que emergem de preocupações de ordem ambiental, econômica e social" 
A dimensão conceitual do Ecoturismo foi detalhadamente examinada por vários especialistas no assunto e destaca-se a de Paulo Santos Pires (1988) escreve: “... o ecoturismo ao voltar-se para ambientes naturais e culturas autóctones deve comprometer-se com a sustentabilidade ambiental, social, cultural e econômica de todos os segmentos sociais envolvidos; deve proporcionar educação ambiental e despertar a consciência ecológica além de contemplar a participação ativa das comunidades locais, critérios estes que uma vez perseguidos na prática, subtraem a dimensão ecológica do ecoturismo, tornando-o apenas turismo na natureza"(PIRES, 1988, p.75)

O artigo do Professor Pires analisa definições propostas por ambientalistas, entidades governamentais, do trade, acadêmicos e consultores e conclui que a falta de unanimidade quanto à definição não significa a impossibilidade de se dar início à atividade turística em ambientes naturais:.."é consenso entre as principais personalidades envolvidas com o estudo do tema, que não surgiu ainda uma conceituação ou definição universalmente aceita por todos os setores com interesse no ecoturismo, e que essa ausência não implica em limitação ao desenvolvimento efetivo das atividades que se realizam em nome do ecoturismo.” (PIRES, p.86)

O presente trabalho optou pelos conceitos de WCU e Western/1997, que sugerem que a atividade turística promova a participação da comunidade em viagem responsável e entende o ecoturismo como o segmento do turismo sustentável, que tem por objetivo, desfrutar, apreciar e estudar os atrativos naturais e culturais das localidades receptoras e tem por prioridade: conservação das áreas naturais, a minimização dos impactos negativos, a educação ambiental desenvolvida junto à comunidade local e turista.

O conceito é valioso também para medir a eficiência da atividade turística junto à comunidade, viabilizando respostas aos seguintes questionamentos: a comunidade participa? Ela é ouvida? A qualidade de vida dela melhorou com o desenvolvimento do ecoturismo? Quais as mudanças que ela promove no local?

Segundo Norman et al (1998), dentre os diversos conceitos é consenso: 
1) Usar liderança adequada e manter grupos suficientemente pequenos para garantir um impacto mínimo no destino. Evitar áreas com manejo insuficiente e supervisitação;

2) Assegurar que administradores, pessoal e empregados contratados saibam e participem da política da empresa para prevenir impactos no ambiente e na cultura local;

3) fornecer programas de treinamento aos administradores, pessoal e empregados contatados. Estes programas devem visar a orientação mais detalhada do visitante dos ecossistemas frágeis;

4) contribuir para a conservação das regiões visitadas;

5) ofertar empregos à população local;

6) oferecer acomodações adequadas ao local, sem desperdício de recursos ou destruição do meio ambiente.

A definição da Western (1997)- The International Ecoturism Society é aceita por diversos autores (Ruschman 1999; Beni-Schiavetetti e Foresti, 1999) e também, pela EMBRATUR: "viagens responsáveis para áreas naturais que preservam o meio ambiente e sustentam o bem estar da população local".

Para o WWF (2001) o ecoturismo "pode ser descrito como turismo realizado em áreas naturais, determinado e controlado pelas comunidades locais e gerando benefícios para elas e áreas relevantes para a conservação da biodiversidade"

Buscando promover o aprofundamento do tema, dentre as definições mais difundidas sobressaem os seguintes importantes pontos: 
1) exploração turística de ambientes naturais;

2) conservação desses ambientes;

3) que o ambiente seja auto-sustentável;

4) educação ambiental;

5) qualidade de vida das comunidades locais.

Assim, a proposta para o planejamento de uma unidade de turismo ecológico, necessariamente, apreciará um belo local que seja natural, que possa desenvolver sua sustentabilidade e que a atividade a ser revitalizada tenha preocupação ecoturística, a de gerar benefícios locais.

\section{2 - AS PRINCIPAIS ATIVIDADES ECOTURÍSTICAS NO BRASIL}

1) Caminhadas e travessias (trekking-hikking): caminhadas simples de até $4 \mathrm{~km} \mathrm{e}$ travessias que percorrem distâncias que levam de 1 a 4 dias;

2) Canoagem: técnica de exploração de rios com corredeiras ou não.

3) Camping: forma mais fácil e econômica de se hospedar próximo à natureza;

4) Boiacrós: divertida descida de corredeira, usando-se bóias infláveis ou pneus de caminhão;

5) Rafting: é a descida de rios com corredeiras e pequenas cachoeiras com bóias super reforçadas;

6) Vôo livre (asa delta): vôos a partir de uma rampa de um morro: 
7) Balonismo: Vôo dirigido pelo vento;

8) Parapente (paragliding) - é um paraqueda dirigível;

9) Ciclo turismo: passeio de bicicletas adaptadas ao terreno irregular;

10) Espeleoturismo: visitação em cavernas;

11) Observação de pássaros (birdwatching) com auxílio de binóculos observa-se, identificam-se e estudam-se pássaros em seu ambiente natural;

12) Escalada em rocha: necessita de equipamentos específicos;

13) Pesca recreativa: amadora ou esportiva;

14) Safári fotográfico: captura de imagens em câmeras fotográficas;

15) Snorkelling: é realizado em rios, lagos e no mar, usa-se máscara, snorkell e pésde-pato;

16) Passeio eqüestre.

Outras atividades de maior impacto são arroladas como práticas do ecoturismo, porém não têm franca aceitabilidade.

\subsection{INSTALAÇÕES ECOTURÍSTICAS}

Segundo o Ministério do Meio Ambiente (2.002)- p.47 e 48, as instalações em projetos para o ecoturismo devem atender os seguintes princípios e critérios: 


\subsubsection{Projeto de edificações}

O ecoturista impressiona-se com o grau de conservação do ambiente e não com projetos imponentes. No projeto de edificações, deve-se utilizar técnicas de construção, materiais e conceitos culturais do local, sempre que esses forem compatíveis com o meio ambiente. As construções devem ser espaçadas para permitir o deslocamento de animais e o crescimento da floresta. Devem ser consideradas as variações climáticas, estações chuvosas e inclinação do sol, utilizando técnicas de ventilação e iluminação naturais sempre que possível. As obras devem ser planejadas, considerando futuras ampliações e evitando demolições e desperdício.

\subsection{2- Construções}

As construções devem estar em harmonia com o meio ambiente natural, utilizandose materiais resistentes, com técnicas que não agridam o meio ambiente. Sempre que possível, deve ser utilizada a matéria prima da região e empregar artesãos e artistas locais, que darão um toque de beleza regional as obras;

\subsection{3- Fonte de poluição}

As possíveis fontes de ruídos, mau cheiro, que podem estar relacionadas com as instalações, devem ser examinadas, para que não perturbem o ambiente ou criem desconforto aos visitantes. Currais e cocheiras para animais de pastoreio devem ficar distantes das fontes de água e de outros recursos hídricos para não causar poluição.

\subsection{4- Organização do espaço}

Atenção especial deve ser dada ao acesso de portadores de necessidades especiais, como cegos, pessoas em cadeiras de roda. O acesso de carros as áreas naturais protegidas deve ser evitado; 


\subsection{5- Trato com ambiente natural}

Restingas, manguezais, matas ciliares e topos de morro não podem ser desmatados. Deve ser evitado cortar árvores de grande porte ou de importância local; só utilizando aquelas que sofreram quedas naturais.

\subsection{6- Trilhas e sinalizações}

Nas trilhas, devem ser mínimos os pontos de travessia de igarapés e riachos. As sinalizações devem ser adequadas, com painéis informativos, placas de identificação e orientações aos visitantes. Há sugestões do IBAMA, quanto aos tipos de sinalização adequados para Unidades de Conservação que podem ser usados para outras áreas.

\subsection{7- Código de conduta}

O código de conduta para visitantes e funcionários em relação ao meio ambiente deve ser fixado num local visível ou apresentado em palestras ou folders;

\subsection{8- Informações}

É bom que se tenha sempre à disposição dos ecoturistas materiais sobre o local a ser visitado, de preferência publicado por instituições científicas confiáveis.

\subsection{9- Consumo de energia}

O uso de produtos que consomem muita energia ou que envolvam materiais perigosos deve ser evitado. É válido considerar o uso de energias alternativas - solar, hidráulica ou eólica, assim como a captação e uso das águas das chuvas.

\subsubsection{0- Lixo e esgoto}


Deve ser implantado e promovido a coleta seletiva, com a separação do lixo: restos de plantas e animais podem virar adubos. Outros materiais podem ser reaproveitados como metais, papéis, vidros e plásticos. Adotar métodos seguros para armazenagens, remoção e redução do lixo, assim como reutilização e reciclagem de embalagens. Reutilizar as águas servidas (já utilizadas nos lavatórios, nos chuveiros, na cozinha) para irrigação de pomares e outras plantações. É necessário providenciar o tratamento do esgoto sanitário e utilizar os nutrientes nele contidos para produzir alimento, sempre que possível, biodigestores que produzem gás natural e um bom composto orgânico.

\subsubsection{1- Produção de alimentos}

Procurar sempre utilizar alimentos produzidos de maneira orgânica, sem utilização de agrotóxicos, priorizando a produção e o consumo de alimentos regionais. As plantações devem estar, de preferência, integradas com as instalações ecoturísticas.

\section{4- BAIXO IMPACTO}

Abordando ainda as questões de sustentabilidade, valemo-nos do capítulo do livro Turismo e Planejamento Sustentável da Professora Doris Ruschmann, de 1999 em relação aos impactos sobre o meio ambiente, que são as seguintes:

1) "Primeiramente, o fato de o homem estar vivendo e modificando a Terra há milhares de anos torna difícil estabelecer uma base para medir as modificações";

2) A segunda razão reside na impossibilidade de dissociar o papel do homem da natureza. Mesmo sem a intervenção humana o meio ambiente se altera, dificultando também as bases para os estudos de impacto;

3) Em terceiro lugar, as complexas interações do fenômeno turístico fazem com que o impacto total da atividade seja quase impossível de medir. Impactos específicos 
ocorrem sobre grupos particulares de pessoas, tais como as minorias raciais ou culturais, ou sobre tipos únicos de vegetação ou espécie de vida selvagem;

4) A quarta razão reside na descontinuidade espacial e temporal entre causa e efeito; Por exemplo, a erosão em determinada área pode ocasionar depósitos mais adiante, prejudicando o fluxo das águas e provocando a extinção da fauna e flora. Um espaço de tempo transcorrerá até que todos os impactos de uma atividade se tornem aparentes;

5) A quinta razão metodológica situa-se na seleção dos indicadores, criando a questão sobre quais deles utilizar e o que significam. Um problema complementar apresenta-se na atribuição de valores aos indicadores selecionados uma vez que a importância dos impactos varia nos diversos sistemas estudados.

\section{5- ECOVILAS}

"Atualmente, considera-se que para atingir a sustentabilidade, nossa forma de viver tanto quanto a forma de organização de nossa comunidade precisa se modificar."

O conceito mais popular de ecovilas, de acordo com André Luis Soares, (Instituto de Permacultura e Ecovilas do Cerrado - IPEC /1988) traz a solução mais abrangente (local e global), de um assentamento completo, de proporções humanamente manejáveis, que integre as atividades humanas no ambiente natural sem degradação e que sustente o desenvolvimento humano saudável de forma contínua e permanente.”

Enfim, ecovilas são edificações de pessoas que resolveram viver de forma diferente, integradas com a natureza, garantindo suas necessidades básicas e saudáveis de água limpa, alimento, moradia adequada, com saneamento responsável e filosofia de trabalho com a natureza, interação social condizente com as necessidades humanas, diferentes do modo usual.

De acordo com Soares- Instituto de Permacultura e Ecovilas do Cerrado - IPEC, os principais campos de uma ecovila são:

2.5.1 Sistemas de captação, armazenamento, distribuição e reciclagem da água. 
A água é a substância vital e dos oceanos surgiu a vida que habita o planeta. $\mathrm{O}$ ciclo hidrológico de evaporação, transpiração, precipitação e absorção que ocorre na biosfera é a força de propagação da vida.

O cuidado com os recursos hídricos, bem como a restauração daqueles já degradados é responsabilidade das comunidades que se assentam em qualquer microbacia e bacia hidrográfica. As.Ecovilas devem se preocupar com o abastecimento adequado de água potável e para irrigação, armazenando a pluviosidade e melhorando a qualidade das nascentes e córregos existentes. Também o tratamento biológico da água utilizada deve ser uma prioridade. A qualidade da água descartada por qualquer comunidade deve ser igual ou superior àquela utilizada. O planejamento adequado para a utilização das águas superficiais, particularmente do escorrimento superficial que ocorre em áreas pavimentadas, telhados e solos descobertos, é um fator a mais a ser considerado.

\subsubsection{Sistemas de geração de energia renovável.}

A prioridade, dentro da política energética local, deve ser para a conservação e economia de energia. Busca-se a utilização de aparelhos e instrumentos mais econômicos e a mudança de atitude cultural em relação ao desperdício de energia elétrica.

A produção de energia para uso industrial ou doméstico demanda uma quantidade incalculável de recursos, além de causar sérios problemas de poluição atmosférica. Toda ecovila deve investigar as origens locais da energia reticulada, para estabelecer sua procedência e seu impacto ambiental. Esta investigação pode levar a conclusão quanto às quantidades de energia serão necessárias para a sustentação da comunidade local. Existem muitas tecnologias para a geração sustentável de energia renovável: solar, micro-hidráulica, eólica, biogás. É de responsabilidade de todo assentamento investigar as alternativas mais viáveis e 
calcular o investimento necessário e tempo para amortização, levando em conta as características específicas do local.

\subsubsection{Redução das necessidades de transporte}

Ecovilas definem um estilo de vida que, por sua natureza, demanda pouco dos recursos de transporte, particularmente do transporte de alimentos e materiais. O transporte de pessoas também é reduzido com a criação de postos de trabalho locais. Com o natural embelezamento do ambiente, tornam-se desnecessárias as "escapadas" para o mundo natural, comum em populações urbana estressadas.

Neste caso, a natureza faz parte da rotina de todos e as viagens longas são menos urgentes.

Para aquelas necessidades de transporte inevitáveis, existem alternativas comunitárias cooperativas, e mesmas tecnologias eficazes que barateiam o custo e reduzem (ou eliminam) a poluição e a degradação do ambiente.

Certamente que uma ênfase na coletivação do transporte é necessária para o desenvolvimento de estratégias sustentáveis a nível regional.

Ainda ficam por serem resolvidas as questões de transporte a longas distâncias. Eventualmente, quando os custos reais passarem a ser refletidos em todos os meios de transporte, a sociedade deverá encontrar seus caminhos, reduzindo as necessidades e investindo em tecnologias apropriadas.

\subsubsection{Acesso a facilidades de comunicação}

Com sistemas de comunicação eficiente, as necessidades de transporte são muito reduzidas. Basta compararmos os efeitos que tais tecnologias, como o telefone, telefaxes e modems têm causado na comunicação entre as pessoas. 
Sem que se elimine as interações pessoais, ecovilas necessitam considerar, tanto as suas formas de comunicação interna (quadros de aviso, boletins, intranets.), quanto às conexões com o mundo exterior;

Cada ecovila do planeta necessitará de um centro de informações, onde as comunicações diárias entre as comunidades e destas com o mundo, possam ocorrer. Assim, espera-se evitar o isolamento que hoje é imposto às populações rurais, e em uma escala maior, o isolamento imposto aos países menos industrializados.

\subsubsection{Estruturas Físicas}

O ciclo planetário de transformação da energia solar em matéria, a partir da fotossíntese, alimenta a base para a sustentação da vida. Em uma comunidade humana a medida do respeito por este ciclo é representada pelas ações tomadas em direção a um equilíbrio biorregional dos recursos utilizados com aqueles produzidos.

\subsubsection{Produção e Consumo de alimentos e necessidades básicas}

O sistema econômico e social que exige o transporte do alimento produzido localmente para cidades distantes, é um processo que alimenta a especulação e empobrece a região. Ao mesmo tempo a deposição dos resíduos e poluentes deste processo é, em grande parte, levada para fora da cidade, depositando nas zonas previamente férteis dos vales rurais.

A produção orgânica e permanente de alimentos deve ser uma atividade de todo e qualquer assentamento, com um mínimo de 60 a $80 \%$ de auto-suficiência alimentar, para suprir as comunidades, inclusive nas zonas urbanas. 
Embora algumas trocas regionais possam ser encorajadas, a alimentação básica das famílias é responsabilidade inalienável. Isto não significa que todas as pessoas devem se engajar na agricultura. Pelo contrário, uma família dedicada a esta tarefa, e com suficiente espaço disponível pode alimentar outras oito famílias, que podem se dedicar a outras necessidades.

Todas as regiões do planeta devem priorizar a produção de alimento saudável, orgânico e diversificado em abundância para seus habitantes, além de delimitar áreas específicas para o desenvolvimento natural dos ecossistemas locais.

A comercialização inter-regional de alimentos específicos, fibras e outras especialidades, só deveria existir, uma vez que a condição básica de alimentação tenha sido alcançada.

A Permacultura é um sistema que orienta para este fim. $\mathrm{O}$ australiano Bill Mollison desenvolveu uma síntese do conhecimento ancestral indígena com o melhor da ciência experimental moderna para criar um sistema de planejamento e produção integrado com a natureza.

O objetivo é a eficiência energética máxima em todas as interações de um sistema vivo. Desde a localização das habitações até a criação de florestas de alimentos e ecossistemas aquáticos, a Permacultura permite a concentração da produção das necessidades humanas básicas em pequenos espaços.

\subsubsection{Arquitetura e construção ecológica}

Quando os assentamentos sustentáveis são o objetivo, o projeto da construção das edificações deve respeitar o bom senso em relação à utilização prioritária de materiais locais, não tóxicos, além das técnicas apropriadas para a participação comunitária na construção de suas habitações. 
A indústria da construção civil é responsável pelo maior consumo dos recursos naturais no planeta. Florestas, metais e outros recursos são utilizados com enorme desperdício, em prejuízo das futuras gerações.

Enquanto isto, $3 / 4$ das habitações do planeta são eretas com o material mais básico: a terra e permanecem por séculos. Além da argila, palhas, pedras, madeiras, podem substituir a grande maioria dos materiais utilizados na construção civil.

É muito importante que haja uma revisão dos valores pessoais, particularmente relativos aos conceitos estéticos. Ecovilas são bonitas, as casas são confortáveis e eficientes e seus habitantes se beneficiam da saúde proveniente de uma habitação não tóxica.

\subsubsection{Considerações ao ciclo de vida dos materiais}

Antes da aquisição de um objeto, trazendo-o para dentro do sistema, deve-se refletir quanto ao ciclo de vida dos materiais utilizados neste objeto:

Será que existe mesmo a necessidade da compra?

há conserto?

poderá ser reciclado?

poderá ser substituído por outro, feito de materiais naturais?

A análise do ciclo de vida dos materiais já faz parte das organizações empresariais mais avançadas e está intimamente relacionada aos conceitos de qualidade.

\subsubsection{Restauração dos ecossistemas naturais}

A recuperação dos ambientes naturais é responsabilidade de toda a espécie humana e, por analogia, de qualquer ecovila. A redução das quantidades de solo fértil no planeta é o problema mais urgente que enfrentamos. As florestas, mangues 
e sistemas aquáticos da Terra também têm sofrido uma degradação sem precedente, em sua maioria, devido às atividades humanas.

Todas ecovilas devem engajar-se em programas de plantio de florestas, eliminação de erosão e recuperação das áreas degradadas nas suas regiões.

E o Prof. Manoel Cláudio finaliza:

"Para isso, faz-se necessário o conhecimento da vegetação local, espécie prioritária para os plantios (alimento para a fauna, lenha carvão) e estabelecimento de práticas de manejo sustentáveis que respeitem o crescimento da floresta, permitindo a retirada somente do que a floresta cresce anualmente. Ciclos de colheita de diferentes produtos devem ser estabelecidos em função das características de crescimento da floresta manejada".

\subsubsection{Estruturas Sociais e Econômicas}

Decisão e Governo a nível local: o fluxo de informações em uma comunidade determina a forma com que esta é organizada, como os elementos sociais são estruturados. Assim, uma organização vertical, hierárquica, estabelece um sistema em forma de pirâmide, onde as decisões são concentradas por uma minoria na ponta, e a grande maioria permanece fora de contato e alienada.

Por outro lado, um fluxo circular de informação permite que todos participem, de alguma forma, no processo decisório, particularmente naquelas decisões que tenham impactos diretos nas suas vidas. Os conflitos e os rumos de uma comunidade são decididos com a participação de todos aqueles que venham a se beneficiar ou ser atingidos pelas decisões tomadas. Um assentamento não pode ser muito numeroso, para que todos tenham voz e acesso às suas lideranças.

2.5.11 Quadro Comparativo entre as populações de assentamento (adaptado de Bill Mollison e Christopher Alexander) 


\begin{tabular}{|l|l|}
\hline \multicolumn{1}{|c|}{$\mathbf{N}^{\mathbf{0}}$ de pessoas } & \multicolumn{1}{|c|}{ Atividades } \\
\hline 30 a 40 & $\begin{array}{l}\mid \\
\text { mínimo número de pessoas para cobrir a maioria das } \\
\text { funções humanas }\end{array}$ \\
\hline 200 a 300 & mínimo para a variabilidade genética humana \\
\hline 600 a 1.000 & $\begin{array}{l}\text { máximo para o relacionamento pessoal e a } \\
\text { representatividade de todos }\end{array}$ \\
\hline 1000 a 5.000 & máximo para uma federação de ecovilas \\
\hline 7.000 a 40.000 & $\begin{array}{l}\text { cidade funcional somente, se organizado em vilas ou } \\
\text { cooperativas confederadas }\end{array}$ \\
\hline 50.0000 & máximo para uma cidade organizada \\
\hline
\end{tabular}

\subsubsection{Sistemas Econômicos locais}

A medida em que o mundo se adapta a seus limites naturais, novos sistemas de economia comunitária deverão evoluir com as populações. O momento exige que "reinventemos a economia de modo a satisfazer as necessidades reais das comunidades e regiões".

\subsubsection{Sistemas de saúde preventiva}

A maior parte dos custos que hoje são provenientes de um sistema de saúde que trata da doença sem eliminar a causa, poderia ser economizados, com um estilo de vida saudável, em ambiente apropriado.

\subsubsection{Educação para as realidades}

Todo assentamento tem um compromisso com a formação da consciência e a capacitação para o trabalho de seus habitantes. O crescimento e a satisfação são atingidos a partir de um sistema que reconheça as particularidades e as vocações individuais, sem negligenciar as necessidades de sobrevivência do grupo. A Ecovila tem também a responsabilidade de educar e conscientizar seus vizinhos, dentro e além da região. 
O programa de voluntários segue os padrões internacionais da WWF (Trabalhadores interessados em fazendas orgânicas), onde os interessados são convidados a preencher um formulário e aguardar a chamada e se chamados, ficam por um espaço de tempo, trocando as horas de trabalho por alimentação, acomodação e capacitação em Permacultura e Ecovilas.

\subsubsection{Estruturas culturais}

Ecovilas são assentamentos seguros que garantem a expressão pessoal, artística ou espiritual de seus habitantes, sem, no entanto comprometer o espaço privado de cada um. A diversidade cultural de uma comunidade é a oportunidade para o desenvolvimento de uma verdadeira visão global no mundo

Uma nova consciência global pode emergir desta diversidade reconhecida, protegida e celebrada nos festivais, ritos e feiras.

\subsection{PERMACULTURA}

A Permacultura é uma forma de utilização mais abrangente do espaço e é regida por alguns princípios que são selecionados a partir da ecologia, conservação de energia e ciência ambiental e em resumo são as seguintes:

1) localização relativa: cada elemento (casa, tanques, estrada) é posicionado em relação ao outro, de forma que se auxiliem mutuamente;

2) cada elemento executa muitas funções;

3) cada função importante é apoiada por muitos elementos;

4) planejamento eficiente do uso de energia para a casa e os assentamentos;

5) preponderância do uso de recursos biológicos sobre o uso de combustíveis fósseis; 
6) reciclagem local de energias humanas e de combustíveis;

7) utilização e aceleração da sucessão natural de plantas visando o estabelecimento de sítios e solos favoráveis;

8) policultura e diversidade de espécies benéficas objetivando um sistema produtivo e interativo;

9) utilização de bordas e padrões naturais para um melhor efeito.

Os elementos, em uma pequena vila poderão incluir: casa, viveiro, de plantas, horta, galinheiro, tanques de água, pilhas de composto, caixas de abelhas, estufa, árvores, quebra vento, pilha de lenha, galpão, barracão de ferramentas, alojamento e minhocário (compostagem e húmus) que deverão estar posicionados para um bom funcionamento.

Cada elemento executa muitas funções, por exemplo: um tanque pode ser utilizado para irrigação, dar água aos animais, cultivo de plantas aquáticas e controle de incêndios.

A permacultura abrange educação ambiental, economia e sociologia e possibilita o desenvolvimento de ambientes produtivos, provendo abrigo, alimento, uma perfeita infraestrutura social, resultado da ecocultura na prática.

\section{7- PLANEJAMENTO POR ZONAS}

Esse planejamento trata do posicionamento dos elementos de acordo com a quantidade ou a freqüência em que os utilizamos ou necessitamos visitá-los.

O zoneamento é decidido a partir de número de vezes que se precisa visitar os elementos (planta/animal/estrutura) e vice-versa.

Exemplo: anualmente, visitaríamos o galinheiro: 
1) trezentas e cinqüentas vezes para apanhar ovos;

2) vinte vezes para recolher esterco;

3) cinco vezes para apanhar galinhas;

4) vinte vezes por outras razões.

A zona zero - é o centro das atividades (casa, galpão ou vila), a zona é preparada para a conservação de energia e para ajustar-se às necessidades de seus ocupantes.

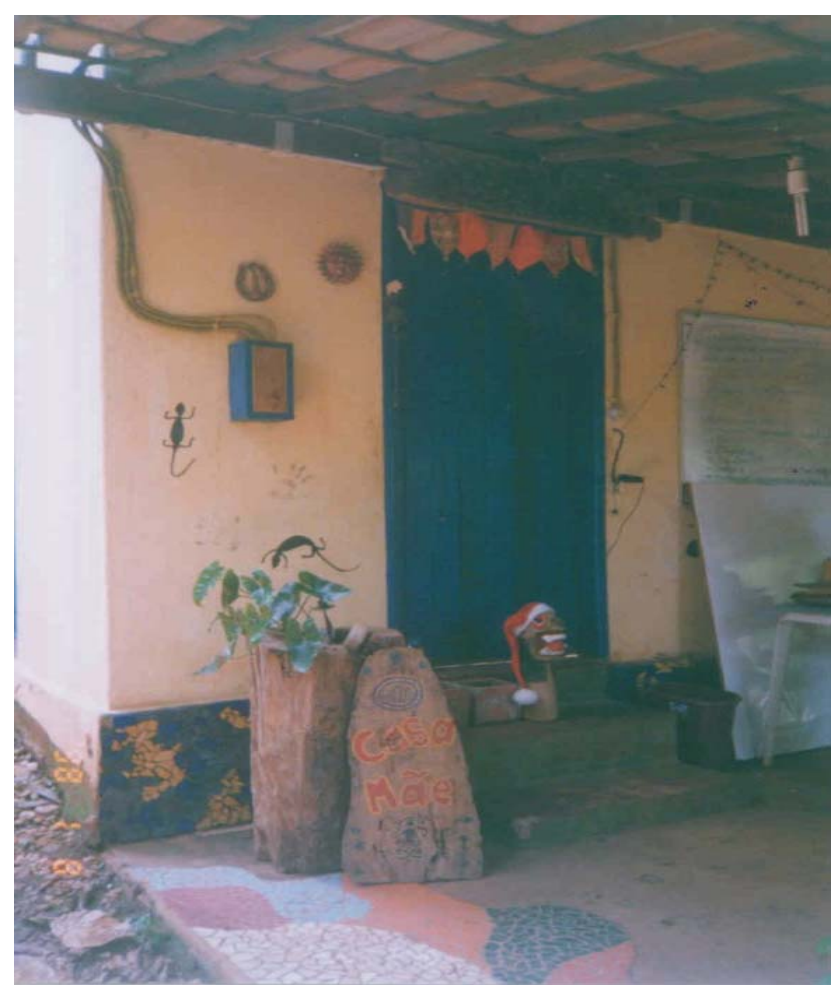

Figura 1 - Casa Mãe/ Instituto de Permacultura e Ecovilas do Cerrado - IPEC

A zona I - é a mais controlada e utilizada. Fica perto da casa e produz a maior parte do alimento e pode conter: jardim, oficinas, estufas, pequenos animais como coelhos. Varal para roupas, um limoeiro, uma bananeira. 


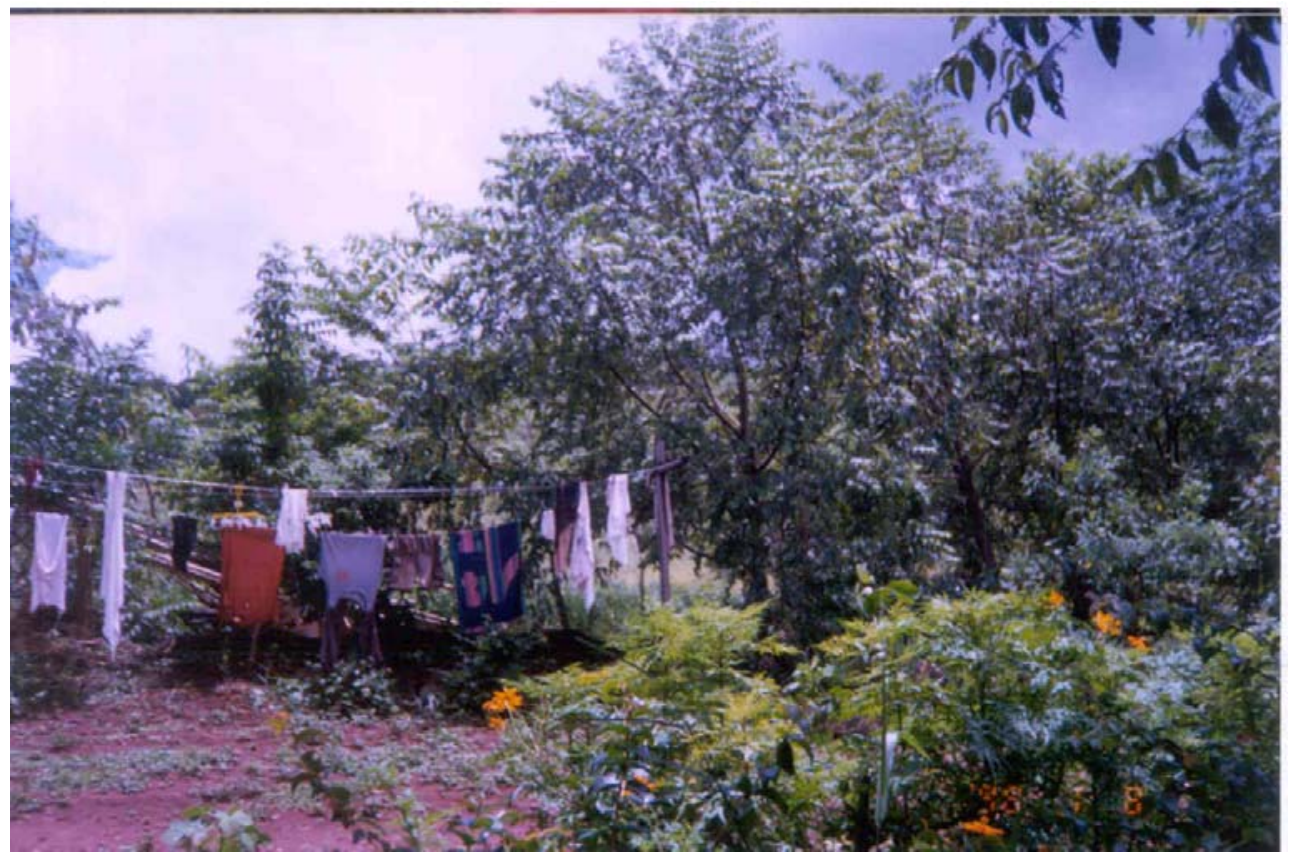

Figura 2 - Varal de roupas

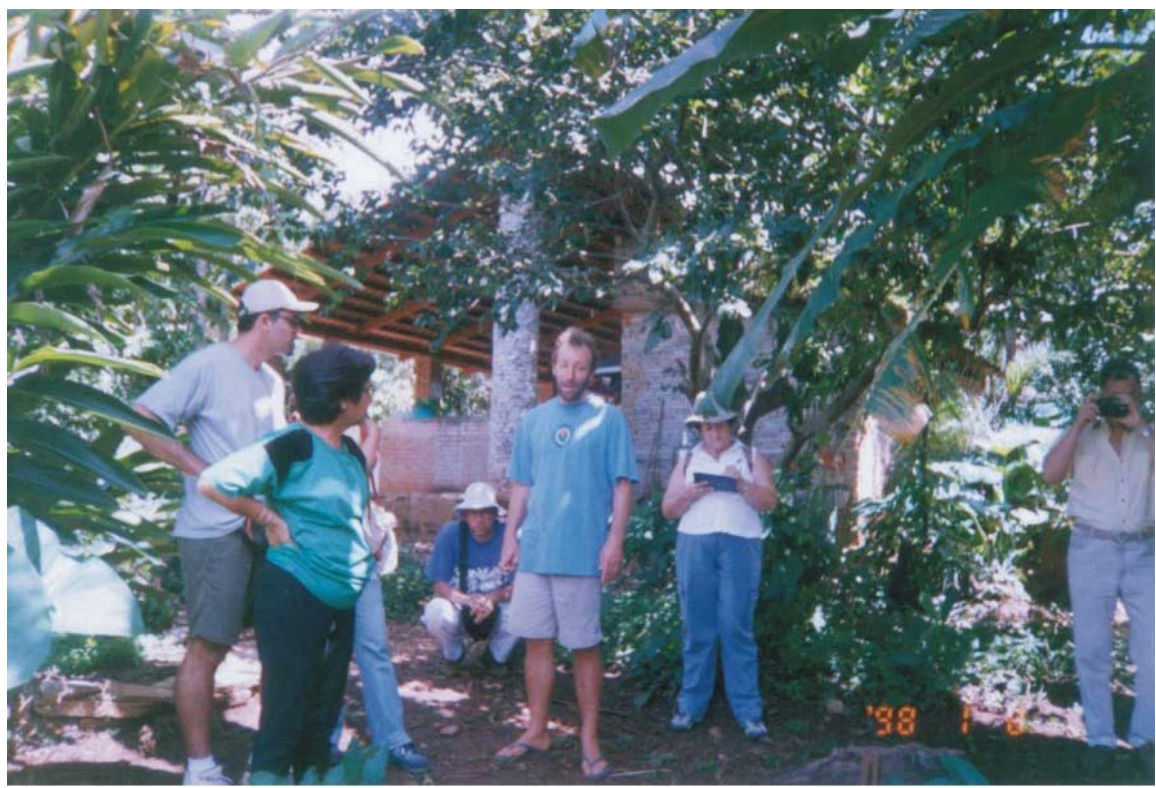

Figura 3 -Jardim, bananeiras/ Instituto de Permacultura e Ecovilas do Cerrado - IPEC.

A zona II - mantida intensamente com plantio denso (arbustos maiores, pomares mistos, tanques, árvores de pequenas frutas e a água é reticulada (irrigação por gotejamento para árvores). 
A zona III contém pomares não podados; A água é disponível apenas para algumas plantas e pássaros semimanejados.

A zona IV - é semimanejada: de vida selvagem e floresta;

A Zona V - não manejado: selvagem, aqui, só se observa e aprende, é local para meditação.

Padrões zonais podem mudar, mas sempre organizados sem que se percam as conexões, elos preciosos para o suprimento de água e energia, esgotos e cercas.

Finalmente observaremos a inclinação, o local em perfil, anotando elevações relativas, para o posicionamento de açudes, tanques de água ou vertentes.

\section{8-TÉCNICAS PARA CONSTRUÇÃO DE HABITAÇÕES SAUDÁVEIS}

As construções em nosso país não levam em consideração as grandes diferenças climáticas, culturais e econômicas. O Instituto de Permacultura e Ecovila de Pampa, sediado em Bagé-RS e o Instituto de Permacultura e Ecovilas do Cerrado - IPEC Cerrados-GO têm prestado assessoria e soluções para construções sustentáveis e que se não são um fim em si mesmas, criam novas perspectivas para a habitação para diversos profissionais, como: arquitetos, engenheiros, veterinários, professores, agrônomos, médicos, técnicos agrícolas, o que evidencia a busca maior de conhecimento nesta área. $\mathrm{E}$ de acordo com Sérgio Pamplona, no seminário sobre Ecoturismo promovido pelo Centro de Excelência de Turismo da Universidade de Brasília - CET/UnB, em novembro de 2.002, cita os princípios da bio-arquitetura, segundo S.V.D. Ryn, que são: “ as soluções brotam do local; o design vale-se da contabilidade ambiental; projetar com a natureza, tornando-a visível e toda a comunidade participam ou projetam": 
Os materiais da bioarquitetura ou ecoconstrução são: taipa de pilão (utilização da terra compactada para a construção de muros portantes; as paredes melhoram a qualidade do ar, não emitem toxinas, são resistente ao fogo e não alojam insetos);

Fardo de palha;

Superadobe, (utilização do solo compactado e ensacado) adobe, (barro com pequena quantidade de areia, bem sovado e moldado em formas de madeira); Taipa leve;

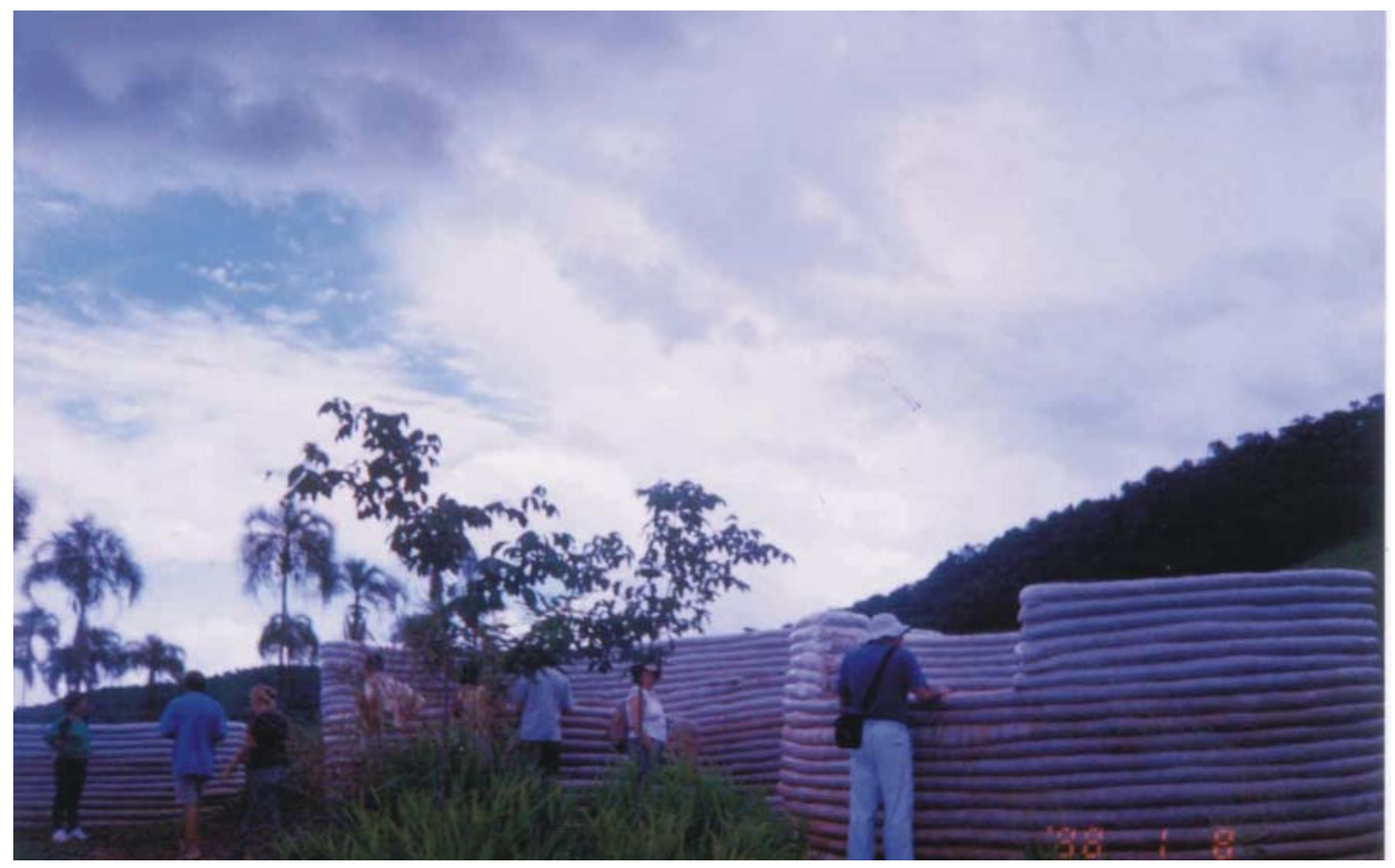

Figura 4 - superadobe/ Instituto de Permacultura e Ecovilas do Cerrado - IPEC

Taipa leve;

Telhado vivo (madeira serrada grossa e compensado, ou bambu, que além de renovável, é muito mais resistente);

Ferrocimento, (malha de ferro de construção, malha plástica, cimento e areia, utilizado para reservatório de água de grande porte, paredes, sauna).

Taipa de mão (COB) é semelhante ao adobe: areia, água, palha, misturados com os pés, e as mãos para formar bolas de terra e dar forma a construção); 


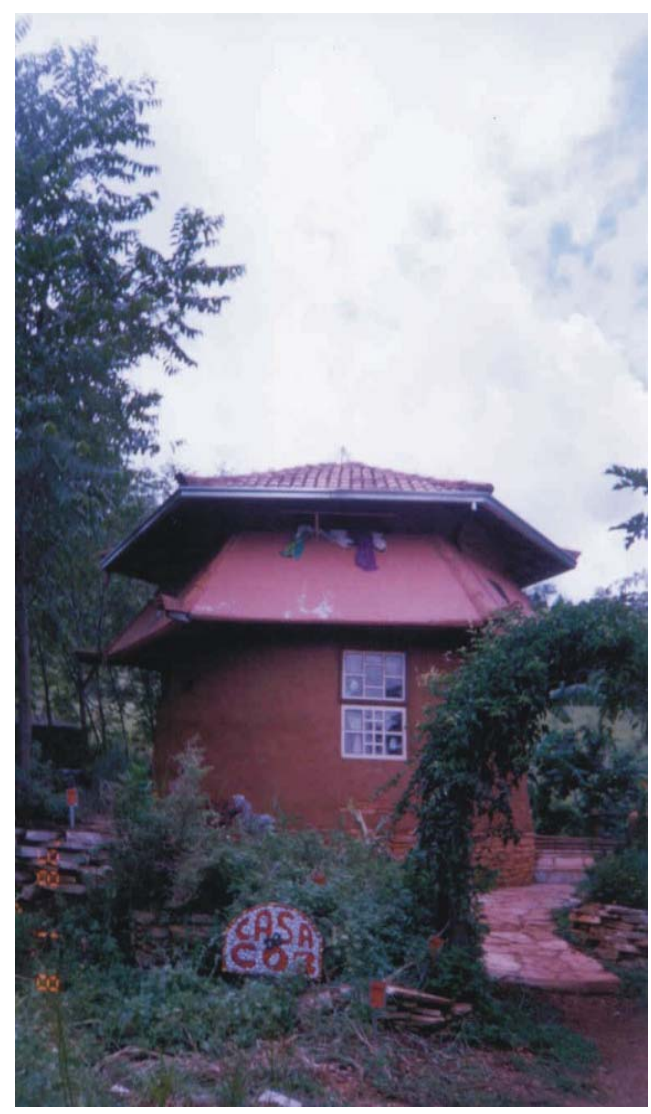

Figura 5 - Casa de COB/ Instituto de Permacultura e Ecovilas do Cerrado - IPEC

Bambu, telhado de fibra vegetal;

Rebocos naturais (é feito com uma mistura de areia fina, argila peneirada e água), estruturas de pedra;

As tecnologias apropriadas utilizadas foram as seguintes: cisternas em ferrocimento, coleta de água da chuva, biomanejo de águas cinzas (servidas-usadas) sanitário seco (compostável), energia solar, eólica e sauna rústica a vapor.

\section{9- SANITÁRIO COMPOSTÁVEL}

Jenkins argumenta que o mundo ocidental moderno sofre de uma enfermidade psicológica conhecida como fecofobia, ou seja, medo das fezes. Os sintomas deste mal se salientam na expressão das pessoas quando se sugere que "deveríamos ser responsáveis pelas fezes que produzimos, que não basta puxar a descarga e esquecer: reações 
exageradas de riso, nojo ou ira são comuns. Com isso se cristalizam tabus que persistem até mesmo nas camadas mais esclarecidas ou mais alternativas da sociedade.

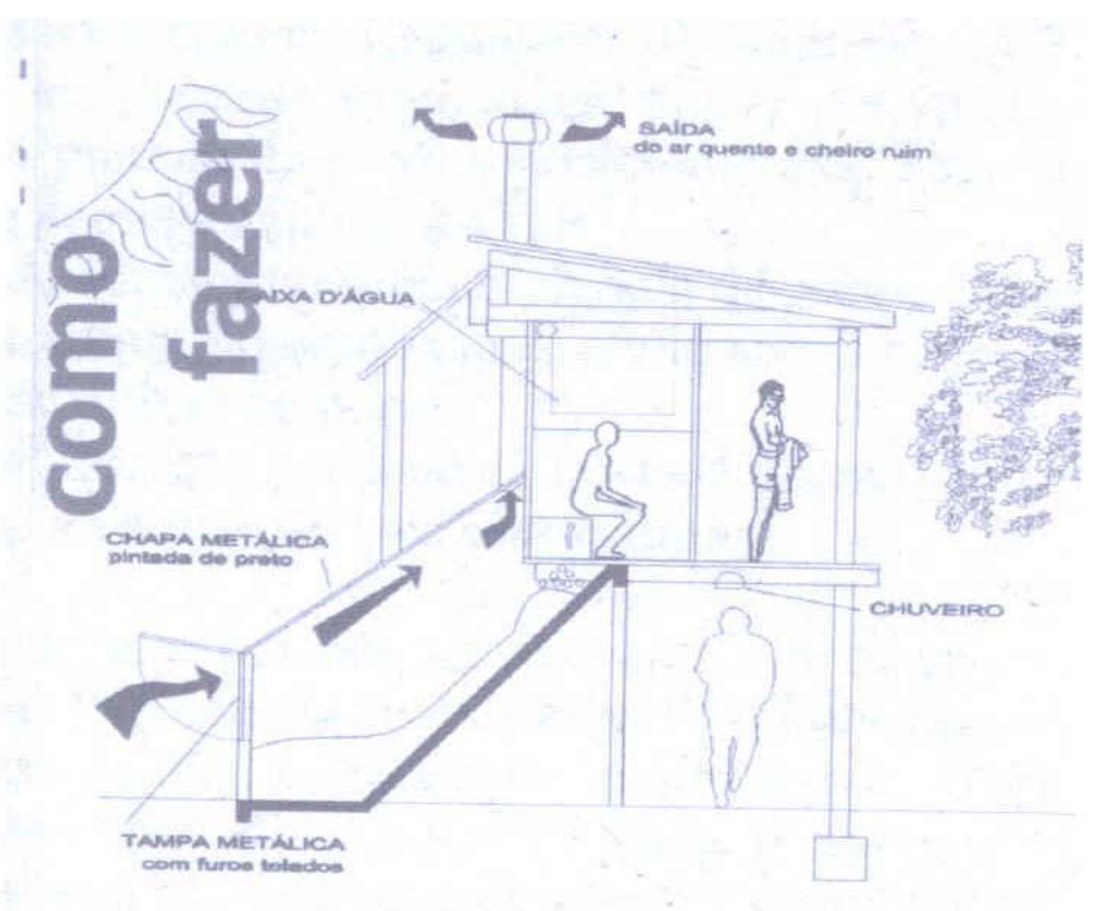

Figura 6 - Sanitário compostável, cópia de imagem. Revista Permacultura, Ano III, nº 7.

Um dos processos mais simples para a eliminação de patógenos humanos nas fezes transformando-as em adubos orgânicos é a compostagem termofílica (amigos do calor). Neste processo, alguns dos microorganismos (bactérias e fungos) são ativados com aumento da temperatura, e rapidamente se multiplicam para digerir este material, tornandoo inócuo e valioso para adubação de plantas.

Para que isso aconteça com as fezes humanas, basta que se adicione o mesmo volume de algum material rico em carbono, como serragem . 
Assim, a mistura fica com uma proporção adequada entre Carbono e Nitrogênio (trinta para um) e começa a se decompor e esquentar, permitindo a multiplicação dos microorganismos e transformando a mistura em composto. Para que a compostagem ocorra de forma segura, sem complicações no manejo, os pontos mais importantes a considerar são:

1) o material deve ser depositado em uma câmara fechada, que não permita a entrada de insetos, outros animais ou de chuva;

2) cada vez que for utilizado, uma quantia similar de material seco (de preferência serragem) deve ser adicionada;

3) a câmara necessita ficar sem uso por um período mínimo de três meses após a última vez que foi usada;

4) O volume interno da câmara deve ser no mínimo $1 \mathrm{~m}^{3}$.

No Instituto de Permacultura e Ecovilas do Cerrado - IPEC foi construído um sanitário com duas câmaras de alvenaria, seguindo um modelo bem sucedido. Os pontos cruciais que garantem o funcionamento do sanitário seco são:

1) $\mathrm{Na}$ parte inferior da portinhola existe uma entrada de ar, vedada aos insetos, que garante a oxigenação constante da pilha. Este ar passa por sobre a pilha e é sugado pela chaminé, sem permitir que nenhum mau cheiro alcance a área de ocupação humana;

2) A chaminé ultrapassa a cumeeira do sanitário em 1 metro, fazendo com que os ventos dominantes dispersem qualquer odor. Esta chaminé é pintada de preto e posicionada ao norte do sanitário, para que esteja sempre exposta ao sol;

3) A tampa da câmara também é pintada de preto, e transmite o calor do sol para a pilha, aumentando a eficiência do processo. Esta tampa também deve ficar ao norte; 
4) A tampa do assento permanece fechada quando não em uso, evitando assim, que a ventilação seja interrompida.

Enfim, o sanitário não precisa ser tão alto e nem sobre pilares, conclui Sérgio Pamplona: "pode aproveitar o perfil de um terreno inclinado, com cuidado para não deixar a inclinação muito baixa. As câmaras de compostagem têm que ficar voltadas para o sol predominante, o que aquece a chapa metálica sobre as mesmas e a chaminé (ambas pintadas de preto), criando um efeito de circulação de ar, que faz com que o ar fresco seja sugado pelos telados da porta metálica em baixo, subindo rente à chapa, à medida que se aquece e saindo pela chaminé junto com os gases e cheiros".

\section{3- MATERIAL E MÉTODOS}

Para sugestão de práticas sustentáveis a serem aplicadas no SPA ZEN Arte Vivenda, foi feita visita de campo ao Instituto de Permacultura e Ecovilas do Cerrado IPEC - Pirenópolis em fevereiro de 2003. O Instituto de Permacultura e Ecovilas do Cerrado - IPEC foi fundado em junho de 1998 para criar modelos de construção de sustentabilidade, fica próximo a Pirenópolis-GO, a 160 KM de Brasília.

O Instituto de Permacultura e Ecovilas do Cerrado - IPEC foi fundado em junho de 1998 para criar modelos de construção de sustentabilidade apropriados para a realidade do Cerrado e do Brasil. Sua missão resume-se em:

1. inspirar, criando o desejo de mudança a partir de exemplos práticos;

2. informar, alimentando o desejo de mudança com dados completos e apropriados;

3. educar, provendo o apoio técnico necessário;

4. experimentar, oferecendo a oportunidade de testar invenções e soluções ecológicas; 
5. demonstrar que a sustentabilidade rural ou urbana é uma meta alcançável;

6. demonstrar que o foco está nas soluções, não nos problemas;

\section{4- SPA ZEN ARTE VIVENDA}

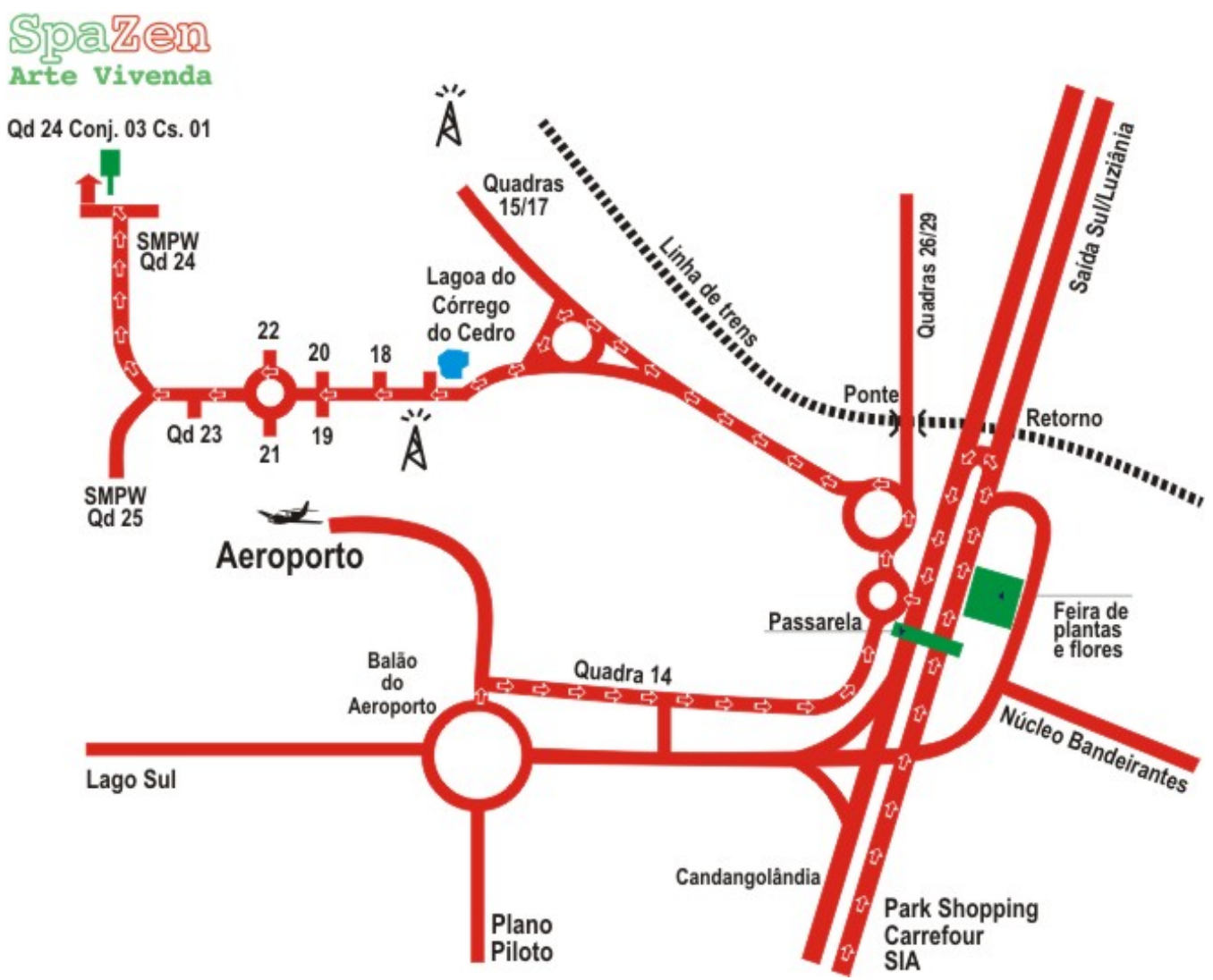

Figura 7 - Mapa de acesso

É um espaço multitemático que está localizado há $10 \mathrm{Km}$ de Brasília, na SMPW, Q. 24, Conj. 03, casa 01, inserida na Área de Proteção Ambiental Gama Cabeça de VeadoAPA criada, em 1986, pelo Decreto 9.417 86, regulamentada pelo Decreto $n^{\circ} 23.238$, de 24 09-02, para proteger as cabeceiras do Ribeirão do Gama e do Córrego Cabeça de Veado e integra a Reserva da Biosfera do Cerrado.

É o local onde se insere o Setor de Mansões, Park Way e o Núcleo Rural de Vargem Bonita, local do presente estudo, porque são áreas onde os usos humanos devem ser 
reduzidos ou condicionados a regras de manejo que não firam a integridade e objetivos das unidades de conservação inserida na Área de Proteção Ambiental Gama Cabeça de VeadoAPA e da própria Reserva da Biosfera do Cerrado. As cabeceiras da Área de Proteção Ambiental Gama Cabeça de Veado-APA são responsáveis por 1/3 das águas do Lago Paranoá. Engloba grande parte do Lago sul, Park Way, Catetinho, Núcleo Rural Vargem Bonita, Aeroporto de Brasília e Candangolândia, conforme informações da Professora Jeanine Maria Felfili.

Dentro da Área de Preservação Ambiental Gama Cabeça de Veado - APA, estão importantes centros de pesquisa, como as Estações Ecológicas da Universidade de Brasília,

Fazenda experimental Água Limpa-UnB, do Jardim Botânico e do Instituto Brasileiro de Geografia e Estatística - IBGE.

\section{1- Histórico do SPA ZEN por José Noguchi, Artista Plástico, Ambientalista, Proprietário, brasileiro sansei, 52 anos.}

As pessoas fazem várias perguntas sobre o SPA ZEN. A história é simples e começou com uma visita ao Atelier de Brenan, no Recife. É um espaço pessoal, artístico, de uma antiga olaria da família, que ele transformou no seu grande atelier e o seu espaço numa mini biosfera. Como artista plástico que sou, disse:

- “Também quero isso para mim".

Vivendo no cerrado, decidi realizar meu sonho de adolescente, morar num terreno grande, não numa casa grande. Daí em diante, busquei encontrar o lugar, até que em 1982, consegui identificar este local, depois de longa procura em cima de mapas de DF e com base em informações de botânicos e corretores de imóveis.

Foi num dia de dezembro de 82 , chovia muito e acompanhado pelo corretor e mais três interessados, aguardávamos a chuva cessar.

Como não parou de chover, todos desistiram, inclusive o corretor desistiu de vender. Contudo, não satisfeito e conhecedor do mapa do DF e da então chamada MSPW 
voltei para casa e com a esposa, mapa sobre a mesa, vimos que este terreno é uma reprodução de tudo o que o Professor George Eiten descreveu há pouco.

Minha primeira preocupação, naturalmente, como qualquer cidadão, foi saber se havia invasões no terreno. Fui o primeiro nesta área, que atrás tem o Ribeirão do Gama e na lateral o Taquara e Gama, que se juntam na mata ciliar mencionada pelo Professor George Eiten, que é uma das formas de vegetação do cerrado. Outras formas são as savanas, outra os murundus, vistos com muita facilidade; Além disso, existem os arvoredos que são as florestas do cerrado, o brejo e os buritis, as matas de galeria, no tapera, que desce em forma de galeria, tudo aqui presente, cercado por quatro grandes Reservas Ecológicas: Água Limpa, à esquerda, a Escola Experimental da UnB, atrás o Morro Roncador, ou seja, Reserva ecológica do IBGE e no primeiro plano, a Reserva Ecológica da Aeronáutica. $\mathrm{Na}$ área formada por duas bacias, no horizonte está quem cuida de tudo isso, o Jardim Botânico. De forma privilegiada, aqui estamos.

Se utilizarmos a criatividade na solução de pequenos problemas e dermos soluções simples a problemas complexos, transformaremos a biosfera do cerra em instrumento de desenvolvimento social e pessoal de forma econômica. Exemplo: exatamente no centro do auditório, vocês podem observar um marco zero, que sempre digo a todos que é o epicentro da biosfera do cerrado. Esta seta indica o Norte e as pessoas, geralmente, perdem o Norte. Este espaço como o Professor George falou, é todo de pedra, todo calcário, mas o impressionante é que na travessia do rio, a terra muda completamente.

Quando da minha chegada, havia e ainda há um invasor que disse o seguinte:

- “o negócio agora vai para frente, porque vem um japonês aí e vai plantar de um tudo". Naturalmente não deu certo. Sempre recebi diversas críticas, inclusive a de que este terreno não valia US\$ 12,000.00, na época que o comprei.

De tanto me falarem que aqui nada adiantava plantar, porque só tinha pedra, utilizei o artifício, a técnica do pensamento paralelo, ou seja, aquilo que nos leva ao exercício da criatividade em busca de soluções simples, lógicas e óbvias, e transformei. Reparem as 
pedras vermelhas que fazem os muros de arrimo e todos os meio-fios, que somam mais de 3.500 metros lineares; são as chamadas tapiocangas. Onde há grama, estavam antes, as tapiocangas que foram retiradas, lapidadas e com o simples barro, reutilizadas dessa nova forma. Um trabalho que durou 15 anos. Conclusão, utilizando os recursos do cerrado, inclusive os parques ecológicos, estamos crescendo, de forma simples, humilde, mas estamos crescendo.

Exemplo: a Vila Tapiocanga é um espaço temático que reproduz um vilarejo do século XVII, em arquitetura portuguesa e estilo barroco. Existem vários equipamentos como: restaurante, prefeitura, delegacia, igreja, banco, a casado médico, grupo escolar, um empório, inclusive a casa das moças mais afoitas, a coletoria e o cartório.Nesses ambientes é que vocês vão trabalhar, por fora é o que falei, mas por dentro, são salas de aula.

De forma bem responsável, estamos explorando essas reservas. O Bernardo, nosso assistente de clientes, nosso gerente, é um trilhador nato. Ele mora na 308 sul e vem trabalhar de bicicleta, percorrendo uma trilha pelo jardim Botânico e Reserva Aeronáutica. Ele tem formado grupos para passeios de trilha, com a duração de uma hora, ao custo de R\$ 2,00 por pessoa, com direito a água mineral, por um caminho até a torre mirante, que a guarda florestal construiu para observar focos de incêndio. É um belo passeio que estamos incentivando.

Procuramos a SEMARH para desenvolver cursos de agentes ambientais, porque acreditamos que não é possível propor projetos de ocupação econômica dentro dos parques, se não tivermos pessoas habilitadas, qualificadas. Por isso o Sistema IEL/SENAI/FIBRA está propondo junto com a SEMARH, ao Ministério do Meio Ambiente, à Divisão de Educação Ambiental, cursos para formação de agentes ambientais e monitores, dentro de nossa vila, que, diga-se de passagem, fazemos questão de ceder para esse tipo de iniciativa.

Basicamente, este espaço se chama Arte Vivenda, uma forma que encontrei para viver com arte, razão também das esculturas. A mata ciliar está intocável, desde que aqui 
cheguei, há 18 anos. Meus companheiros da noite, bandos de capivaras, para os quais plantamos milhos; os tatus, que de vez em quando aparece um para assistir à palestras.

Espero que tenham a oportunidade de observar os pássaros, araras e tucanos que vivem aqui. Também as vacas, cerca de 20 a 30 que pertencem ao invasor e utilizam a vegetação da reserva ecológica com pasto. Não é pasto, mas como disse a Professora Doutora Raquel de Fátima Novelino, é necessário sobreviver. Muitos não têm o conhecimento básico para entender que não devem colocar o gado dentro das reservas ecológicas. Só educando e direcionando as atividades e a exploração das reservas é que mudaremos esse quadro. Nosso papel é esse: informar a população.

Já tivemos aqui, três grupos estrangeiros pára explicar o que é biosfera do cerrado e conseguimos distinguir o ponto em que se vê os quatro biomas do Cerrado."

O discurso acima do proprietário José Noguchi aconteceu no Evento Ecoparques em 22 de setembro de 1999, realizado no SPA ZEN, sob a Coordenação e Promoção da SEMARH, foi o único e definitivo debate sobre a privatização dos serviços nos ecoparques com a recomendação em transformá-los em auto-sustentáveis como a do SPA ZEN 


\section{Mapa das Instalações}

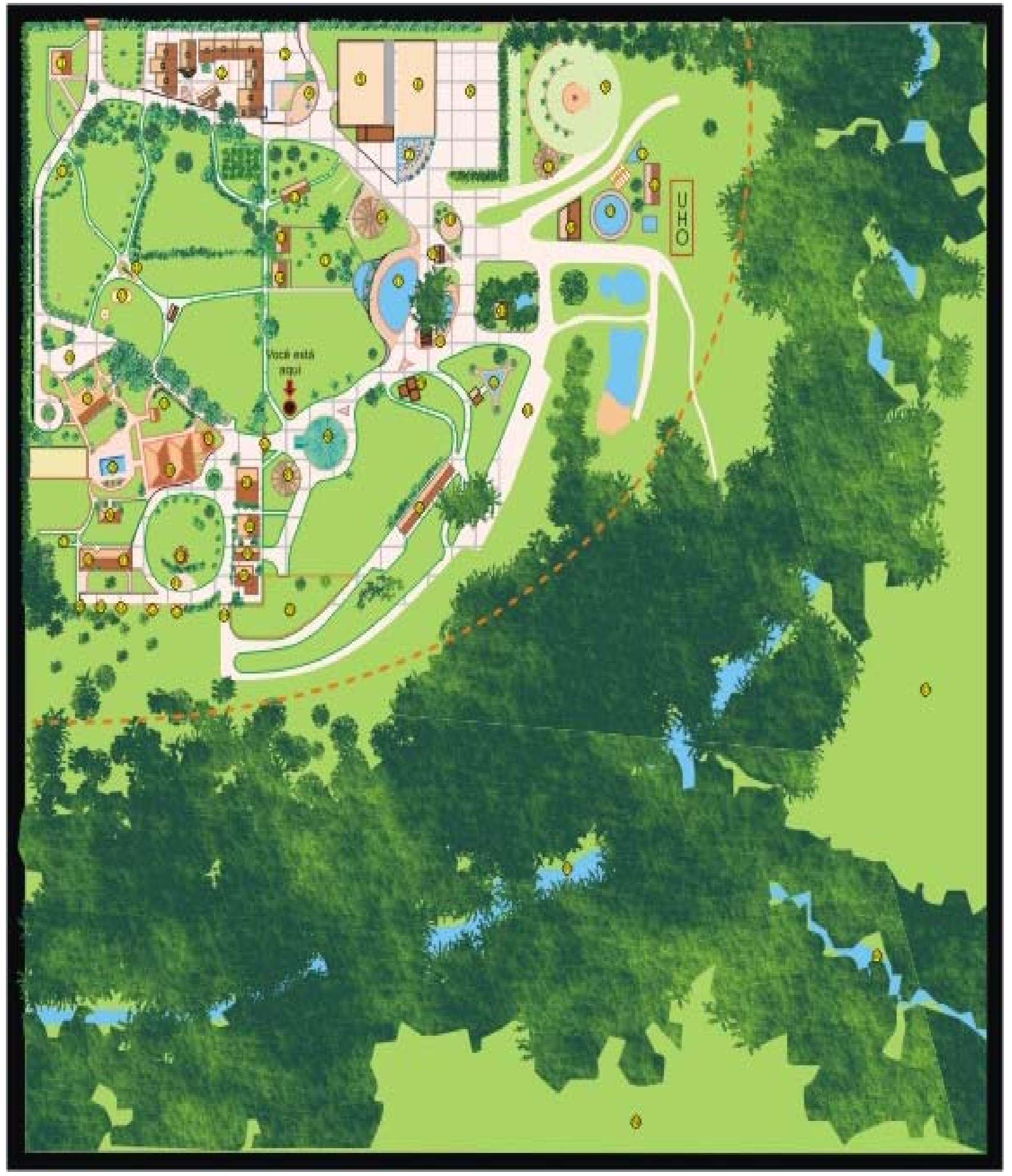


Figura 8 - Mapa das Instalações/SPA ZEN

Legenda:
A Restaurante
12. Casa do Sossego
B. Prefeitura (Coxinha)
13. Galinheiro
C. Delegacia (Refeitório)
14. Bangalô Harumi
D. Igreja (Sala)
15 Viveiro das Aves
E Banco (Sala)
16. Casa da Amizade
F. Casa do Médico (Sala)
17. Lago da Pata
G. Grupo Escolar (Sala)
18. Praça do Sol
H. Casa "Vermelha"
19. Canto do Maikou

(Banheiro)

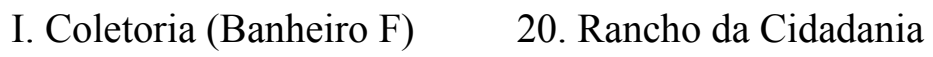

J. Empório (Sala) 21. Viveiro-Jacaré tartaruaga

L. Cartório (Secretaria) 23. Piscina das Carpas

M.

Armarinho 24. Viveiro dos Macacos

(Administração)

1. Pouso dos Corpes

25. Estacionamento

2. Vila Tapiocanga

26. Casa Sede

3. Teatro de Arena

27. Casa de Boneca

4. Praça do Fogo

28.viveiro do tatu

5. Campo de Futebol

29 Casa da Leitura

6 Quadra de Vôlei

30.

Viveiro

das

Corujas/Tanque de Bica

7. Praça Zen

8. Estacionamento (150

vagas)

9 Praça das Bandeiras-

Acompanhamento

10. Piadestal

11. Praça do Arco-Iris 


\subsection{CONSULTAS LEGAIS}

Antes da implantação do SPA, o proprietário José Noguchi, sabedor que um empreendimento como o seu estaria sujeito a um intrincado conjunto de normas e detalhamentos que condicionam o funcionamento da atividade ecoturística em ambiente natural, sem impactos e na perspectiva de eliminação de problemas futuros, fez e continuam fazendo as seguintes consultas legais:

Constituição Federal, art. 225.

"Todos têm direito ao meio ambiente ecologicamente equilibrado";

"Bem de uso comum do povo e essencial à sadia qualidade de vida";

Lei 3.824 de 23 de novembro de 1960 que obriga a limpeza e destoca de bacias hidrográficas dos açudes e represas ou lagos artificiais;

Lei 6.766 de 19 de dezembro de 1979 que dispõe sobre o parcelamento do solo;

Lei 7.335. De 22 de fevereiro de 1989, que dispõe sobre a extinção de órgão e de entidade autárquica, e cria o IBAMA (Instituto Brasileiro do Meio Ambiente e dos Recursos Naturais Renováveis);

Lei 6.902, de 27 de abril de 1981, que dispõe sobre a criação de Estações Ecológicas, Áreas de Proteção Ambiental.

SILVA, J. A. da, disse sobre a legislação ambiental existente até o ano de 1989, sobretudo as Leis 6.902 de 27 de abril de abril de 1981, $\mathrm{n}^{\mathrm{o}}$ 7.661. de 16 de maio e do $\mathrm{n}^{\mathrm{o}}$ 7; 797, de 10 de julho de 89, ambas, criam normas sobre questões ambientais e recomenda que: "Essa legislação ainda não é ideal, pois não insere a sistemática da preservação, defesa e melhoria do ambiente no que se refere à ordenação territorial”. 
Decreto 1.922 de 05 de junho de 1966, que dispõe sobre o reconhecimento das Reservas particulares do Patrimônio Natural;

Os documentos requeridos para os processos de licenciamento ambiental foram:

1)PRAD - (Plano de Recuperação de áreas Degradadas, instituídas pelo Decreto Federal $n^{\circ}$ 97.632, abril de 1989);

2) EIA-RIMA (Estudos de Impactos Ambientais com o Relatório de Impacto ambiental).

3)PCA-RCA (Plano de Controle Ambiental acompanhado do Relatório de Controle Ambiental): são exigidos para empreendimentos que não têm grande capacidade de gerar impactos ambientais.

\section{3 - INSTALAÇÕES ATUAIS}

O estudo do ambiente natural, a questão da sustentabilidade e o impacto ambiental foram motivo das maiores preocupações do proprietário Noguchi, e a sua equipe técnica foi composta por diversos profissionais, de forma que os problemas identificados pudessem ser analisados por diferentes ângulos.

A administração atual é feita pela seguinte equipe:

Gerente Comercial: Bernardo G.de Castro universitário na área de Turismo;

Supervisora de serviços gerais, alimentação, limpeza e manutenção: Marisa M.Tanaka, Pedagoga;

Gerente Administrativo Financeiro: Antonio Yasuaki Tanaka,economista e contador;

Diretor proprietário: José Noguchi, Artista. Plástico, Ambientalista e Publicitário.

Empregados contratados durante eventos: de duas a dez pessoas da comunidade. Empregados fixos: doze pessoas da região. 
Os recursos utilizados foram as observações dos locais mantidos intactos e construídos do local; consultas a mapas do Distrito Federal; pesquisas em Internet, consulta ao manual Orientação para Sinalização Visual de Unidades de Conservação Federais que traz as normas técnicas que devem ser seguidas pelas Unidades de Conservação. É recomendável a sua adoção em empreendimentos como a do SPA ZEN, entrevistas com os Srs; Antônio Tanaka, Bernardo Castro e do proprietário José Noguchi e visitas ao Instituto de Permacultura e Ecovilas do Cerrado, próximo a cidade de Pirenópolis, em companhia do Professor Manoel Cláudio.

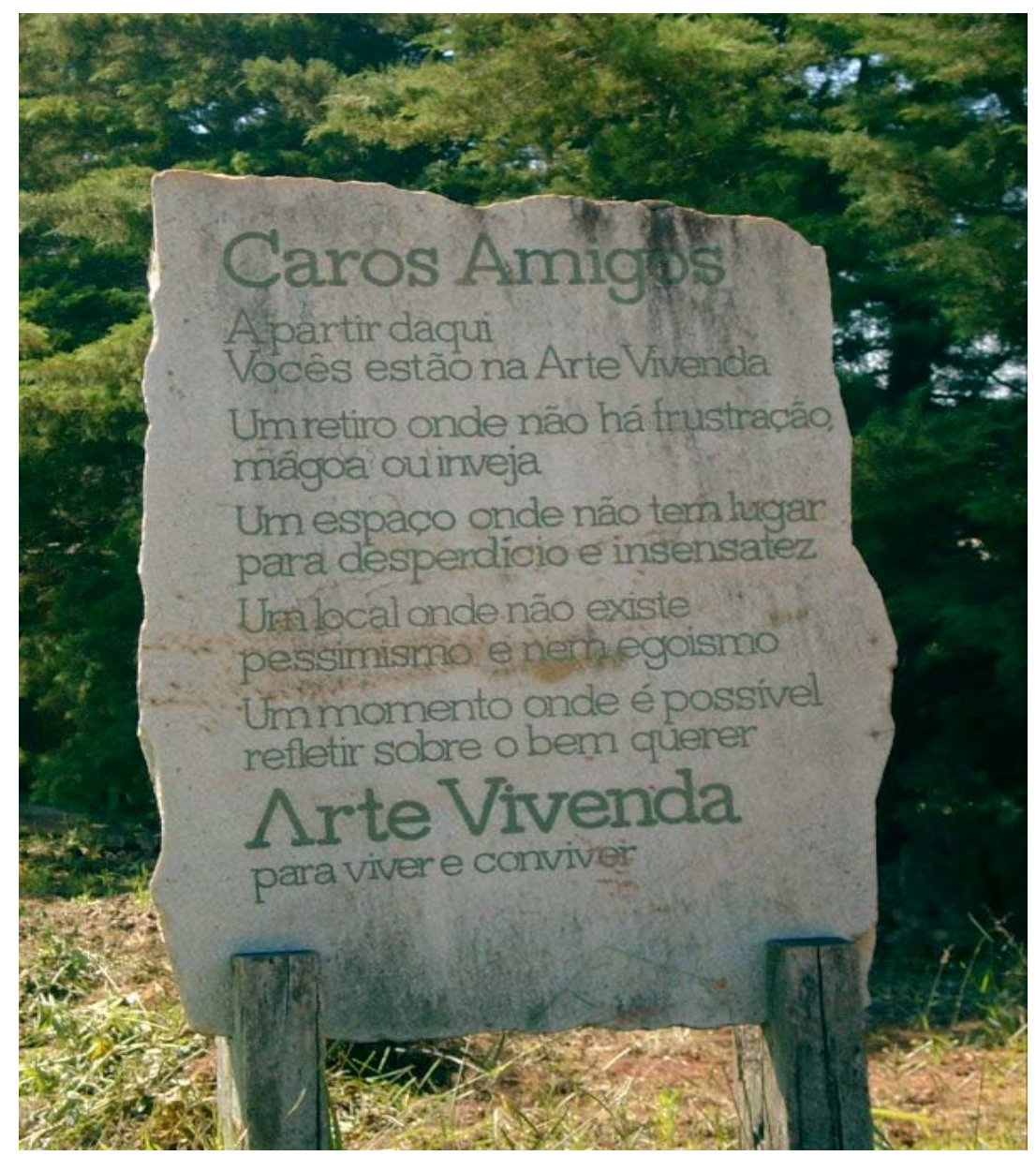

Figura 9 - Placa de Pedra/SPA ZEN

Antes de entrar no SPA, depara-se com os seguintes avisos;

SPA ZEN Arte Vivenda - Para viver e conviver: 


\section{Caros amigos:}

\section{A partir daqui vocês estão no SPA ZEN ARTE VIVENDA.}

Um retiro onde não há frustração, mágoa ou inveja.

Um espaço onde não tem lugar para o desperdício e a insensatez

Um local onde não existe pessimismo e nem egoísmo.

Um momento onde é possível refletir o bem querer.

SPA ZEN Arte Vivenda - Ponto de passagem do vento:

\section{VENTO}

Se vais para o norte, oxigena as nossas ricas florestas.

Se segues para o leste, purifica nossas areias e mares.

Se caminhas para o oeste, leva o seu frescor para os nossos cerrados e pântanos.

Mas, quando soprares para o sul, carrega contigo minhas doloridas saudades, porque é lá onde se encontram meus amados filhos.

Habitação:

Caseiro à direita do portão de entrada,permanentemente, aberto à comunidade local e ao público visitante.

Uma flecha, à esquerda da porta de entrada, indica a direção a tomar, porém as duas são válidas e dependem da escolha para onde se pretende chegar primeiro.

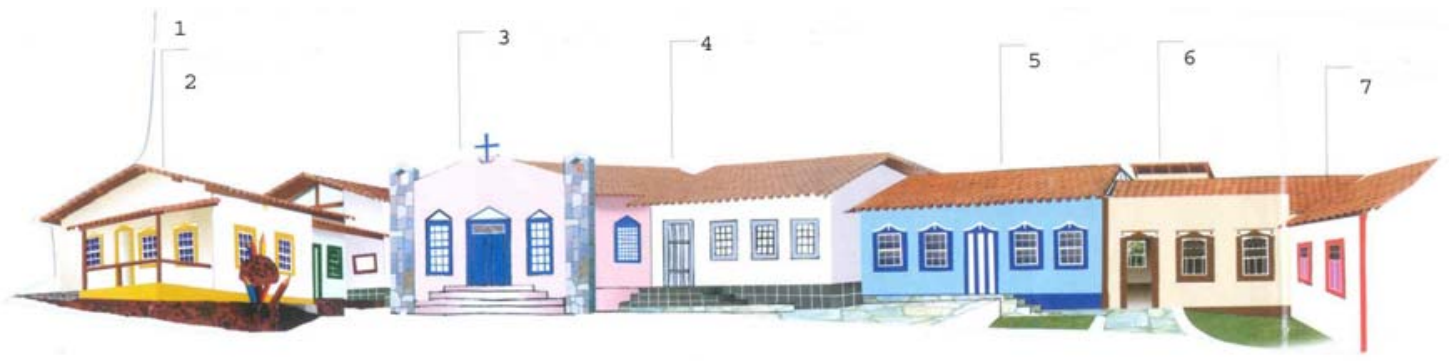


Figura 10 - Vila Tapiocanga/SPA ZEN (vide anexo I)

Legenda:
1) Prefeitura
2) Restaurante
3) Paróquia São José
4) Banco Regional da Lavoura
5) Casa do Médico
6) Grupo Escolar
7) Casa do Senhorio

Uma vila, denominada Tapiocanga reproduz um vilarejo do séc. XVII em arquitetura portuguesa,em estilo barroco semelhante a Pirenópolis-GO, com salas-auditório, destinadas a seminários e eventos, com restaurante, que comporta 300 pessoas; Prefeitura (100 pessoas); Igreja (30); Grupo escolar (40); Cartório de Ofícios (150); e praça, Ranchinho, ou Casa da amizade (50), para palestras sobre educação ambiental e Auditório Rancho Verde, Biblioteca e Salão de jogos, (150); Empório da vila (30).

Cada auditório é preparado de acordo com o evento e $\mathrm{n}^{\circ}$ de pessoas e para usufruir desses espaços, os preços de aluguel dos auditórios, variam entre $\mathrm{R} \$ 150,00$ a 600,00 e a capacidade das salas de aula, entre 25 a 200 pessoas.

Há também um espaço para camping para 100 pessoas e um estacionamento interno para 150 carros.

Há um galinheiro que fornece a alimentação e adubo orgânico, minhocário e húmus.

Relevos e solos:

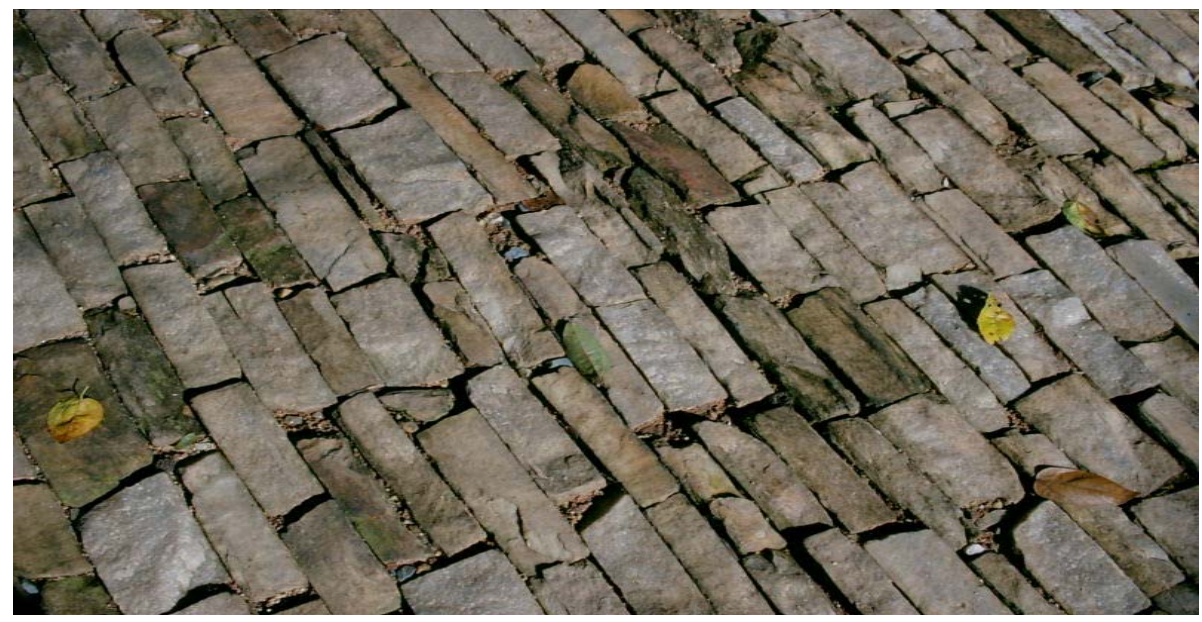

Figura 11 - Solo revestido SPA ZEN 
Em declive, com pedras claras de Pirenópolis, com as lascas reaproveitadas, à semelhança de trilhas calçadas com bloquetes, de modo a permitir que as águas pluviais se infiltrem no solo, beneficiando o lençol freático;

Os muros e meio-fios foram feitas de pedras tapiocangas, retiradas do local, e reaproveitadas da seguinte forma:mistura homogênea de pedras, cimento e barro, que cobrem a pista de mais de 4.000 metros, abaixo.

Recursos Hídricos:

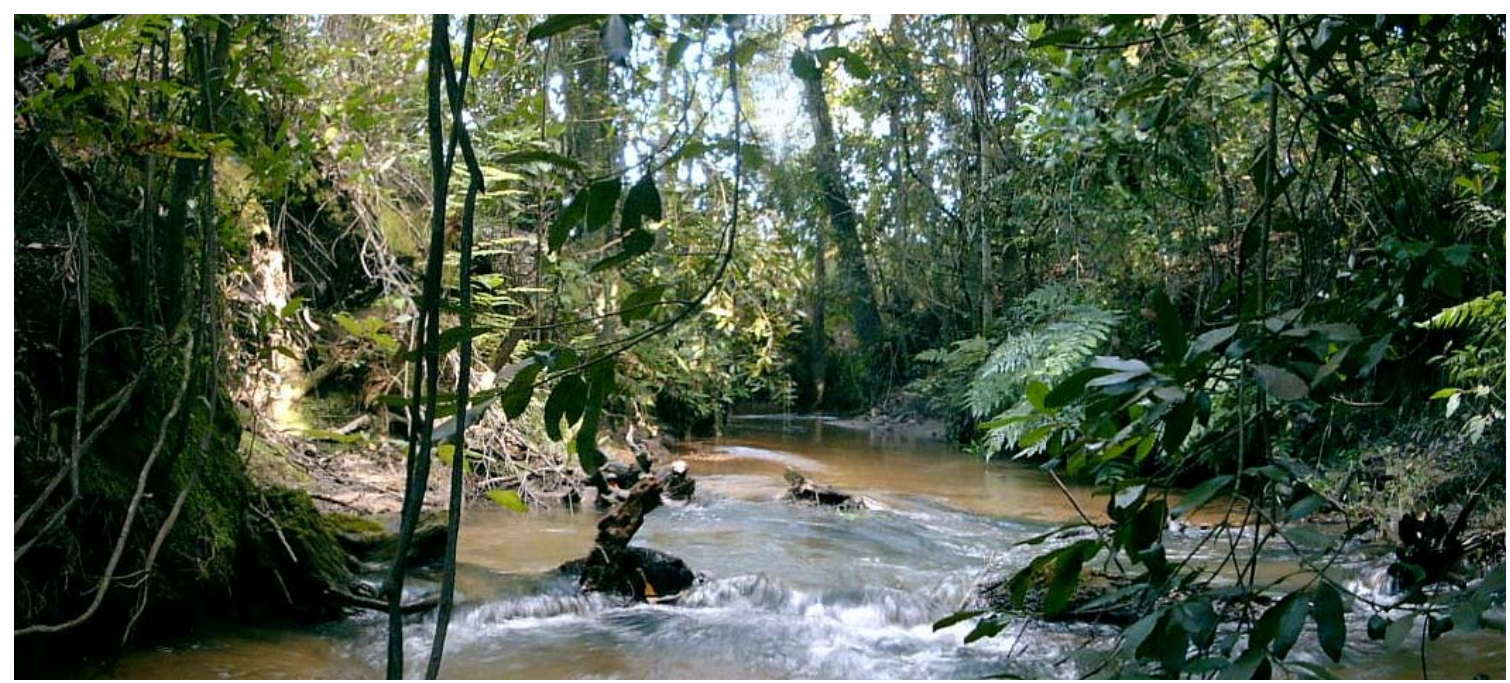

Figura 12 - Rio Taquara/SPA ZEN

Comprometido: existe retirada da água para execução de obras; aparente destruição pelo carreamento de resíduos pela enxurradas no lado oposto do córrego e visível contaminação das águas, por biocida não s ó no SPA, como no Área de Proteção Ambiental Gama Cabeça de Veado-APA como um todo.

O córrego que vem de Vargem Bonita, área de produção agrícola no D.F. chega barrenta, contaminada, imprópria, sendo chamada no local, como braço sujo e o córrego que vem da área da Reserva do IBGE, PAL, apresenta-se cristalino e é chamado de braço limpo. 
Ao lado da pista impermeabilizada por tapiocangas, há dois a três tanques de contensão, ou desaceleradores, que aliviam a pressão das águas pluviais (enxurradas) e são reaproveitadas para irrigação.

Há duas piscinas: uma natural, com as criações de tilápias, patos e cágados. E a convencional para o uso da família.

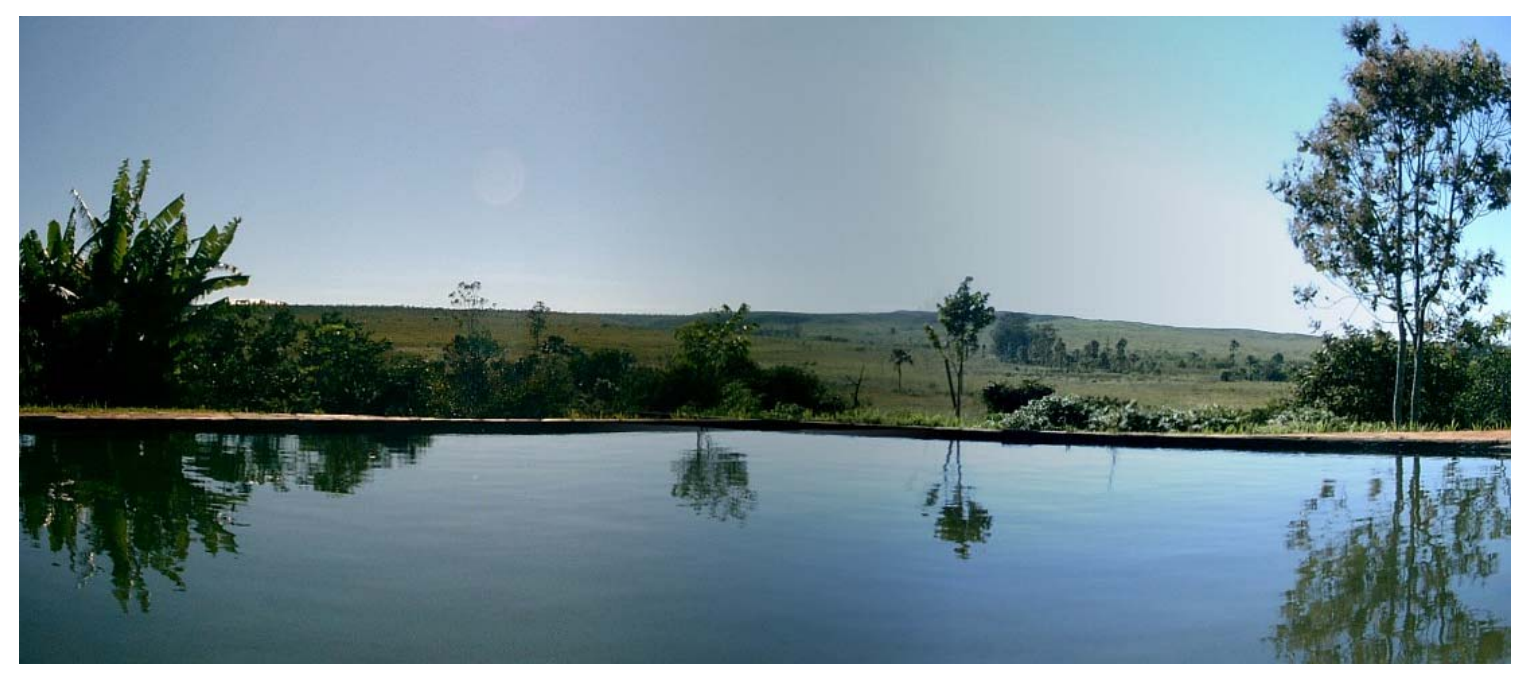

Figura 13 - Piscina Natural/SPA ZEN

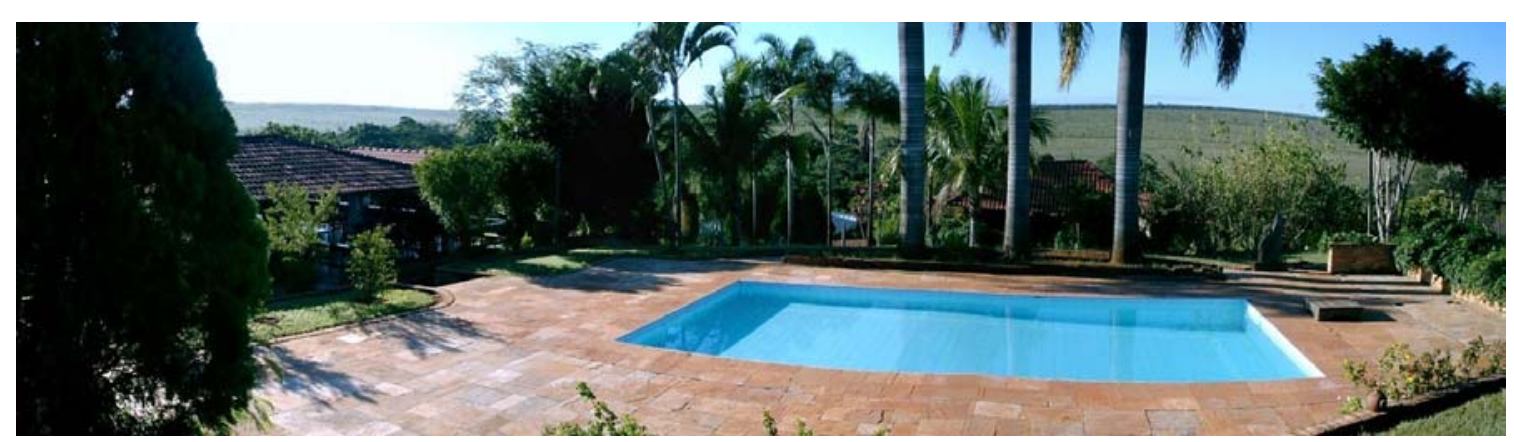

Figura 14 - Piscina Convencional, de uso familiar 
Flora e Fauna:

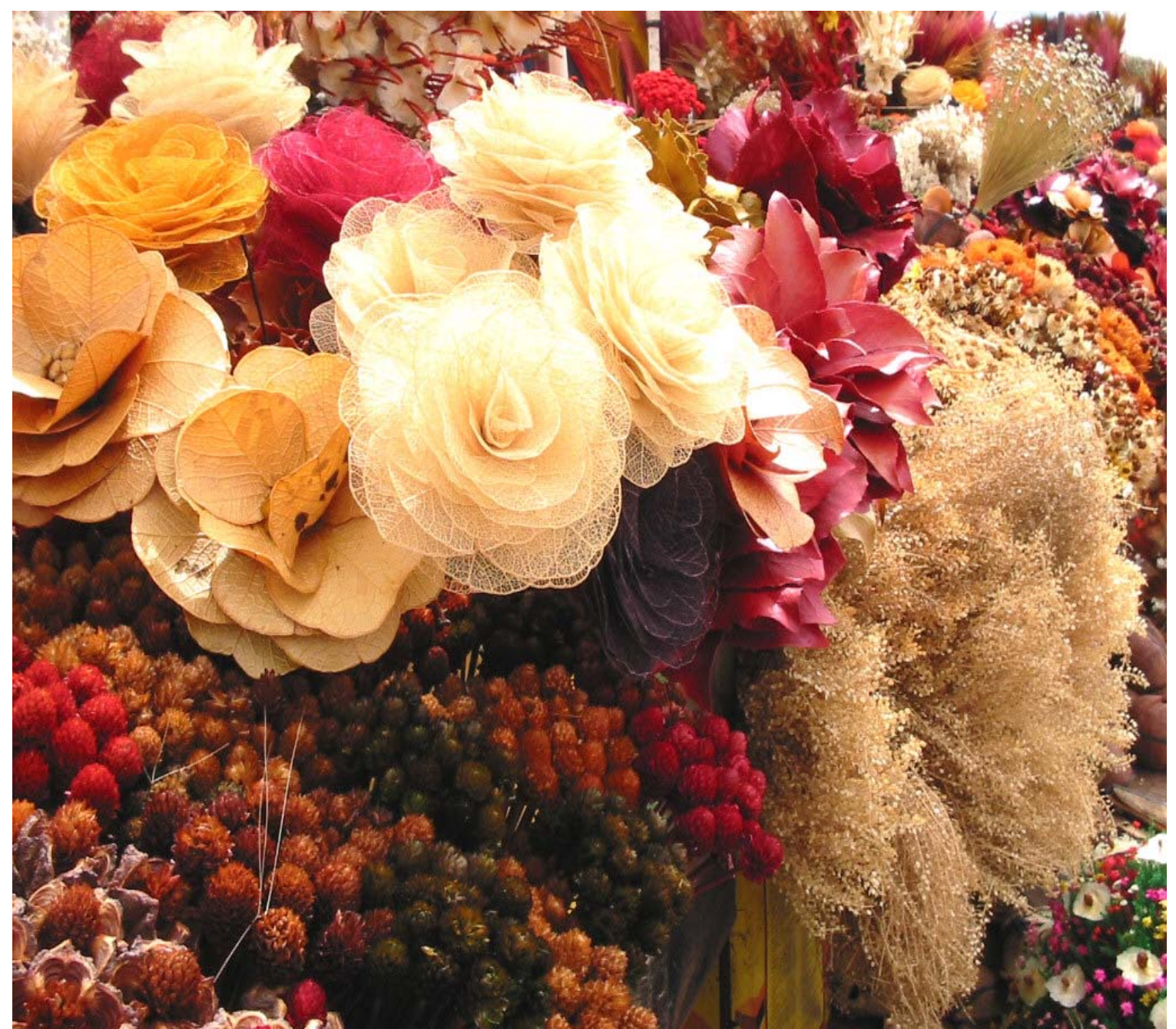

Figura 15 - Flora

Exemplos:

\begin{tabular}{|l|l|l|l|}
\hline \multicolumn{1}{|c|}{ Mês } & \multicolumn{1}{c|}{ Vegetação } & \multicolumn{1}{c|}{ Megetação } \\
\hline Janeiro & Pau-santo e corticeira & Julho & Buriti \\
\hline Fevereiro & Jatobá do Cerrado & Agosto & Pequi \\
\hline Março & Pau de leite & Setembro & Sucupira \\
\hline Abril & Canela de ema & Outubro & Gomeira \\
\hline Maio & Caliandra & Novembro & Pau de Terra \\
\hline Junho & Lobeira & Dezembro & Arnica \\
\hline
\end{tabular}




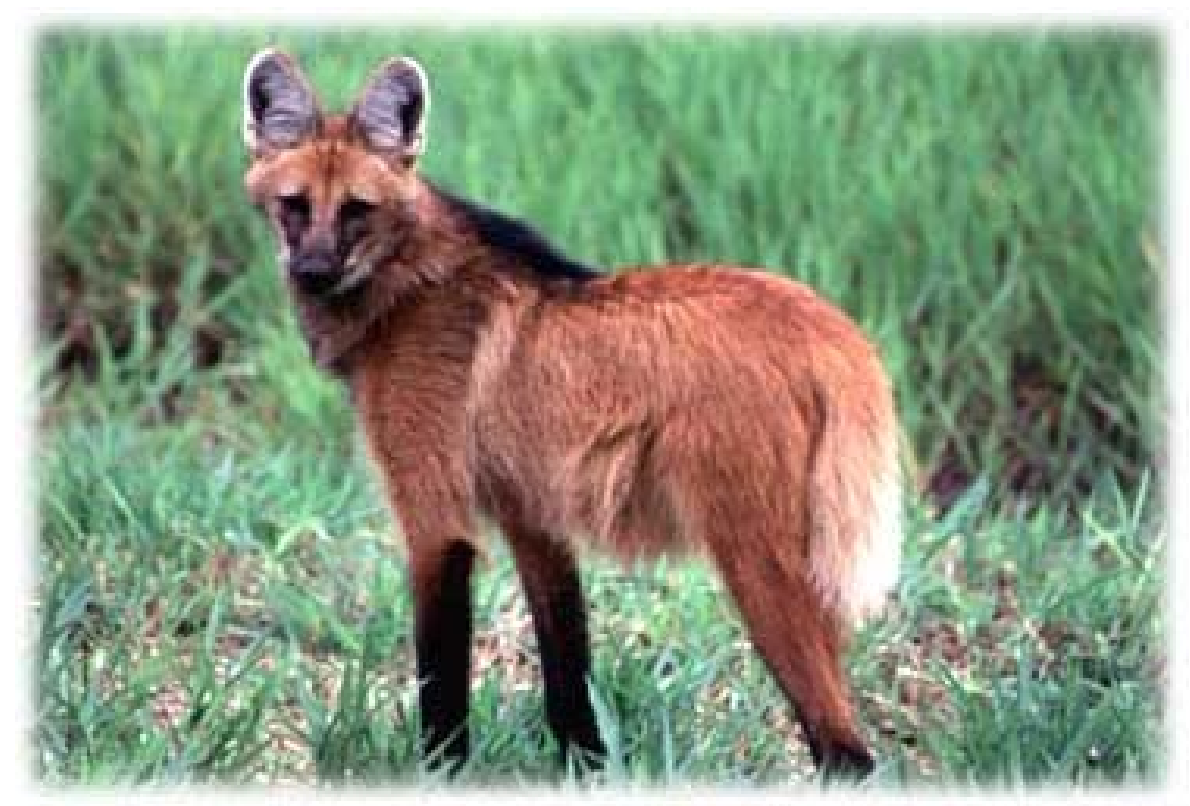

Figura 16 - Fauna

Nas margens dos córregos, onde se encontram as trilhas, verifica-se a existência de matas de galeria intocada, com exemplares de flora nativa do cerrado, como o anjico além de comunidades de murundus e cerrado, preservados.

A Fauna local inclui capivaras, tatus, bugio e lobos-guará.

A churrascaria com capacidade para 200 pessoas, funcionam somente nos eventos.

As Quadras de esportes permitem a prática de futebol, vôlei e peteca.

Esgoto no biossistema ideal, todo o esgoto da casa é encaminhada para um biodigestor, que tem o papel de efetuar a concentração da biomassa e despoluição da águas. (as fossas são impermeabilizadas, biodigestoras), evitando-se ao máximo, infiltração de coliformes fecais, segundo as informações do gerente geral.

\section{4- RESULTADOS E DISCUSSÕES}

A captação da água no SPA ZEN não ocorre como no Instituto de Permacultura e Ecovilas do Cerrado - IPEC, que capta a água de chuva dos telhados e córregos e os armazena nos tanques de ferrocimento. 
No Spa, a água vem da CAESB e quando acontece o uso da água do córrego, o que é raro, a sua devolução é feita após filtragem adequada, através dos tanques/reservatório aeróbico, filtro misto com areia, terra, brita e plantas aquáticas.

A água cinza (usada em banheiros, cozinhas e chuveiros) é reutilizada nas plantações e gramados.

Assim sugere-se a implantação de sistema de captação de água da chuva o que reduzirá sobremaneira a dependência do SPA ZEN da água da CAESB e evitará a necessidade de utilização da água do córrego

O sistema de geração de energia renovável, como a solar, microhidráulica, eólica e biogás, está em estudos para sua futura implantação.

A questão de transportes a curtas e longas distâncias continuam a ser resolvidas por transporte solidários.

Nas áreas impermeabilizadas podem ser projetados sistemas de coleta e distribuição da água da chuva.

A pavimentação por lascas de pedras tapiocangas e de Pirenópolis (reutilizadas) permite que as águas pluviais se infiltrem na terra e melhore o problema do solo e do clima;

As fossas não são secas,como as do Instituto de Permacultura e Ecovilas do Cerrado - IPEC, mas são biodigestoras, há preocupação constante com a contaminação do solo (coliformes fecais). 
A implantação de fossas secas deve ser experimentada podendo assim reduzir a dependência do SPA de água da CAESB, bem como produzir material orgânico suficiente para a horta e a manutenção das áreas verdes locais.

As trilhas até a torre mirante, construído pelo guarda florestal para detectar focos de incêndio e da área intocada, são usadas para passeios.

Os muros de arrimo e meios-fios são originariamente das pedras vermelhas, chamadas tapiocangas (minério de ferro poroso $=$ plintita) que foram retiradas $\mathrm{e}$ transformadas com cimento e barro.

O SPA ZEN promove cursos de agentes ambientais e monitores em parceria com a SEMARH.

O espaço chamado de "Ranchinho" é usado para a educação ambiental para os alunos visitantes;

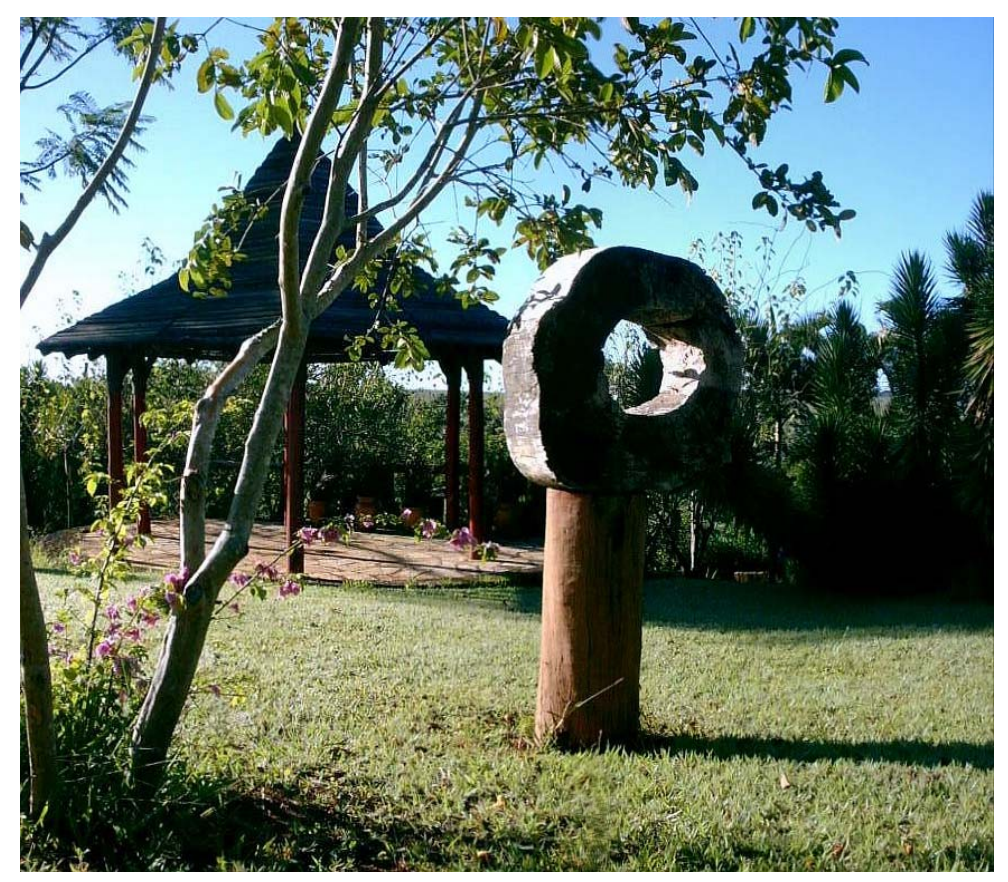

Figura 17 - Ranchinho/SPA ZEN 


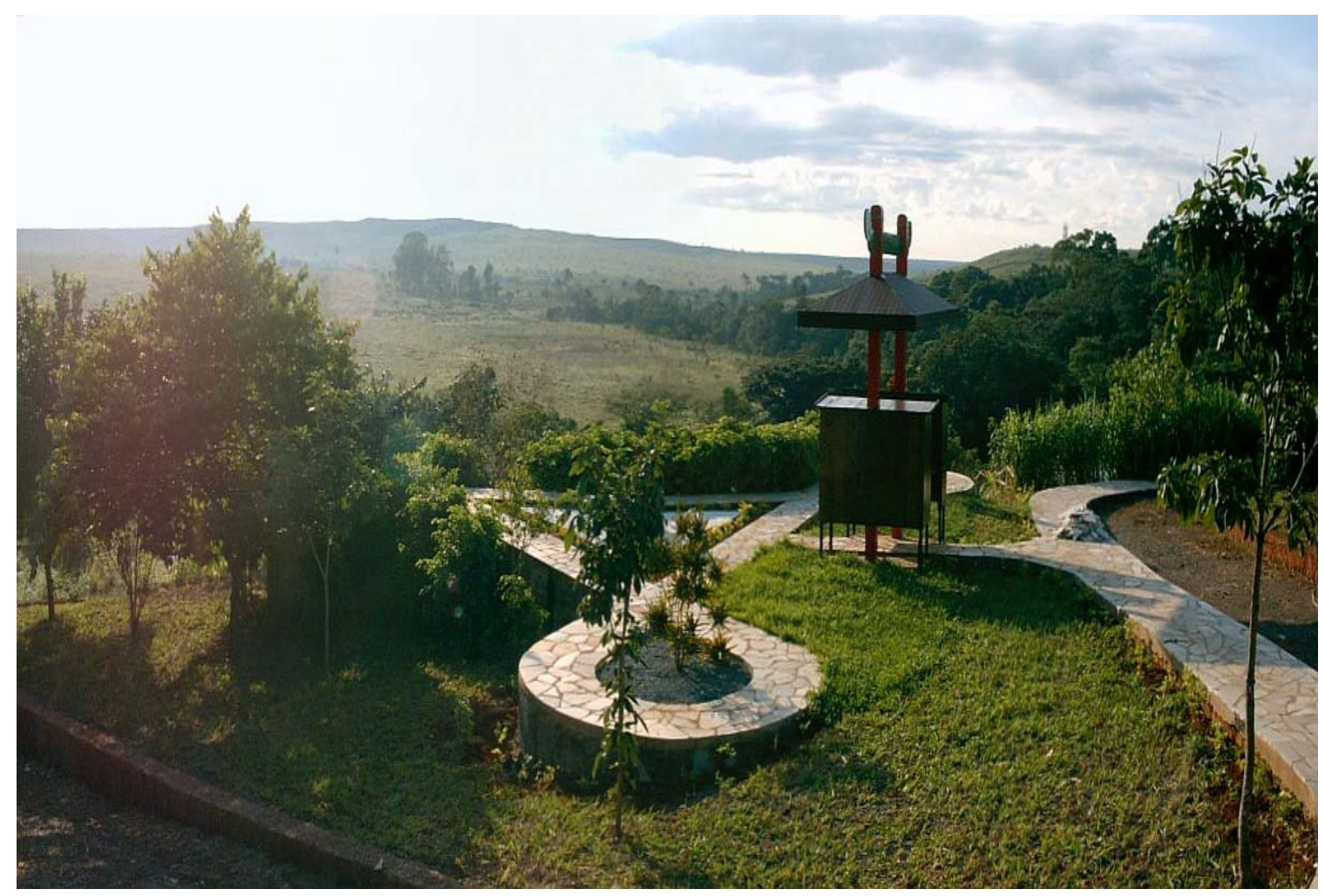

Figura 18 - Praça do Pensar/SPA ZEN

Há uma outra trilha que atende os estudantes da rede pública e particular, divididos em pequenos grupos (dez pessoas)e que são instruídos pelo condutor, nas margens intocadas da mata de galeria.

Devem ser propostas práticas de educação ambienta mostrando como a comunidade florestal é sustentável.

A identificação das árvores e outras plantas no caminho (usando técnicas que estabelecem padrões de tamanho, cor e alfabeto dos elementos) estimula a curiosidade e permite o melhor relacionamento entre o visitante e a vegetação local, de acordo com as normas de Orientação para Sinalização Visual de Unidades de Conservação Federais, sugeridas pelo IBAMA e que podem ser adotadas na área.

O SPA ZEN Arte Vivenda tem toda a infra-estrutura dos centros de treinamento da cidade e é dedicado realização de cursos, workshop, seminários, eventos múltiplos que 
acontecem nos auditórios e salas de aula, no interior da Vila Tapiocanga, (vilarejo do séc. XVII).

Não são permitidas as visitas em massa, bem como as instalações não são disponibilizadas para festas ou encontros religiosos com grande número de pessoas.

Há um pedido para o IBAMA, para que o SPA, seja um fiel depositário dos animais apreendidos, clandestinamente. No futuro, próximo, o SPA terá para o deleite dos visitantes papagaios, araras, tucanos, emas, jabutis, cuidados pela instituição. Os viveiros, já estão em construção e o término previsto para maio-2003.

Tramita na Câmara Legislativa o pedido de concessão do uso econômico da área para atividades do Ecoturismo.

Sugestões a serem discutidas:

1) que se abra o espaço, mediante ingressos a preço razoável, para todos e principalmente para turistas em conexão, tanto dos aeroportos como os da Rodoviária, que têm algumas horas disponíveis antes do embarque para outras cidades:

2) Instalação de uma piscina aquecida, semelhante ao "ofurô" para que o visitante, após a caminhada, possa tomar seu banho e embarcar relaxado para o seu destino;

3) Colocação de placas identificadoras nas árvores nativas do cerrado;

4) Placas explicativas na Praça do Pensar, que é um espaço contemplativo, própria para reflexões, semelhante ao que existe na Legião da Boa Vontade (LBV);

5) Aproveitamento da madeira paletis para uma construção natural ou uma obra de arte, à semelhança das esculturas feitas pelas pedras tapiocangas; e pinturas, reaproveitando as tampas dos barris de gasolina; 
6) Construção da trilha suspensa, monitorada para evitar o pisoteamento degradante nas trilhas na matas de galeria;

7) Sistema de captação de água pluvial através de calhas nos telhados, levando a água para caixas d'água, evitando-se assim, o uso da água do córrego;

8) Construção de uma rampa adequada para portadores de deficiências físicas;

9) Colocação de maior número de lixeiras em vários pontos;

10) Reciclagem do lixo, separando-o em orgânico e seco e comercializando as latas de refrigerantes e vidros;

11) Comercialização de húmus;

12) Livros para registrar elogios e reclamações;

13) A transformação de uso particular da biblioteca para comunitária o que certamente envolverá mais a comunidade local que a revitalizará;

14) Construção de postos de atendimento na entrada com mapas, folders, presença dos guias de turismo ou condutores de trilhas;

15) Guias capacitados para dar informações sobre o SPA e educação ambiental;

16) Venda de souvenirs, como as mini-esculturas feitas de madeira da região, camisetas, chaveiros com motivos ecoturísticos; 


\section{5- CONSIDERAÇÕES FINAIS}

A determinação de prestar o melhor serviço precisa ser dinamizada e ser vista sob um prisma que envolva e alcance vários setores. A consciência da responsabilidade empresarial em ecoturismo deve priorizar: "além do manejo adequado, o conhecimento do sistema natural é a base da verdadeira educação ambiental, quer das comunidades locais, quer dos turistas; a educação está preconizada pelo turismo sustentável.”

O SPA ZEN, como seu próprio nome diz, segundo Noguchi "espaços-locais onde as pessoas buscam tratamentos de recuperação física, reeducação de posturas e alimentares, além de tratamentos médicos. Originariamente, a palavra vem do interior da Bélgica, cujo local tinha um nome com o sufixo spa, onde a realeza e a burguesia européia passavam temporadas para tratamento. SPA ZEN, portanto é um conceito de spa, voltado para o tratamento da mente, de forma espiritual" e tranqüilo que vem proporcionando maiores rendimentos e crescimento interior a todos que o procuram.

Há a necessidade de estimular a comunidade a participar como ator, já que a mesma é a grande avalista do espaço por ela utilizado e cabe a ela mobilizar-se e assumir responsabilidades através do acesso ao SPA ZEN e a coleta e distribuição das informações sobre o meio ambiente.

Os benefícios esperados são as consolidações da consciência ambiental dos moradores da Área de Proteção Ambiental Gama Cabeça de Veado - APA /SPA; maior integração entre o Governo, Especialistas e Moradores; recuperação e conservação da Área de Proteção Ambiental Gama Cabeça de Veado - APA Gama Cabeça de Veado e treinamento para adoção de meios de vida sustentável para as comunidades de chácaras e conseqüente melhoria da qualidade de vida para todos. Se o ecoturismo não for planejado adequadamente, no sentido de poupar os recursos atrativos junto às comunidades, não haverá mais interesse da visitação a longo prazo. 
A questão da educação do visitante deve ser entendida num sentido amplo, de proporcionar-lhe a compreensão e consciência de se preservar a natureza e da prática do ecoturismo de modo adequado.

Determinar a viabilidade de melhorias nos serviços, modificação de alguns já existentes ou combinar os existentes com os novos e finalmente incentivar o envolvimento dos freqüentadores usuais e das comunidades circunvizinhas, através da distribuição de materiais informativos, como folder' $\mathrm{s}$, caminhadas ecológicas, coletas e plantios de sementes, plano de prevenção e combate aos incêndios e ativar o conselho gestor do Área de Proteção Ambiental Gama Cabeça de Veado-APA para orientações futuras de real importância na preservação da área de estudo.

Concluindo, o SPA ZEN é uma grande proposta de ecoturismo, lazer, geração de empregos, espaços culturais, artístico ecológico, comportamental e espiritual. Valoriza a reflexão e a integração total homem-natureza, inserida e revitalizada pela conscientização e preservação ambiental. Enfoca sempre o desenvolvimento sustentável do ecoturismo que está na viabilidade da atividade empresarial do SPA de estar atento na proteção do meio ambiente e do seu desenvolvimento econômico ecologicamente sustentável, com a melhoria da qualidade de vida para os moradores e também das chácaras vizinhas. 


\section{BIBLIOGRAFIA}

BARBOSA \& TRONCOSO - Orientação para Visual de Unidades de Conservação Federais, 1997;

CASTRO, Mário - Plano Estratégico do Turismo - a realidade pioneira, Thesaurus, 1986;

ECOPARQUES - Gestão dos Parques Ecológicos do DF 21 e 22.09.99;

IBAMA, Manual Informativo do Programa Reservas Particulares do Patrimônio Natural - RPPN. MMA-IBAMA, Brasília, 1999;

MOLLISON, Bill \& SLAY, Reny Mia, Introduction to Permaculture, Tradução de SOARES, André Luis J.;

PIRES, Paulo S ,1988 - A dimensão conceitual do Ecoturismo - Turismo, visão e ação v 1,n.1, p.75 - junho/98;

REVISTAS PERMACULTURA BRASIL, $\mathrm{n}^{\circ} \mathrm{s} 1$ ano 1,7 ano III e 1l, ano IV., Publicação AmaTerra;

Revista Ecoturismo - Ministério do Meio-Ambiente, p. 47 e 48;

RUSCHMANN, D. .Turismo e Planejamento Sustentável: a proteção de meio ambiente. Campinas, - Editora Papirus, 1999.p.20-21; 35-36;

SILVA, J.A. de - Direito Ambiental Constitucional, Malheiros, 2000, p.41 Brasília Convention \& Bureau SETUR/GDF

SOARES, André Luis - O que é uma ecovila? < www.permacultura.org.br-IPEC>, acesso em nov.2002;

Obs: A numeração iniciada da Folha de Rosto até o Índice de figuras são numeradas de $1 \mathrm{a}$ 8 em romanos e minúsculas (i a viii). Da Introdução até página de Anexos, de 1 a 53. 